\title{
New Approach in the Application of Conjugated Polymers: The Light-Activated Source of Versatile Singlet Oxygen Molecule
}

\author{
Agata Blacha-Grzechnik (D)
}

check for updates

Citation: Blacha-Grzechnik, A. New Approach in the Application of Conjugated Polymers: The Light-Activated Source of Versatile Singlet Oxygen Molecule. Materials 2021, 14, 1098. https://doi.org/ $10.3390 /$ ma14051098

Academic Editor: Dario Pasini

Received: 30 January 2021

Accepted: 23 February 2021

Published: 26 February 2021

Publisher's Note: MDPI stays neutral with regard to jurisdictional claims in published maps and institutional affiliations.

Copyright: (C) 2021 by the author. Licensee MDPI, Basel, Switzerland. This article is an open access article distributed under the terms and conditions of the Creative Commons Attribution (CC BY) license (https:// creativecommons.org/licenses/by/ $4.0 /)$.
Faculty of Chemistry, Silesian University of Technology, Strzody 9, 44-100 Gliwice, Poland; agata.blacha@polsl.pl; Tel.: +48-322371024; Fax: +48-322371509

\begin{abstract}
For many years, the research on conjugated polymers (CPs) has been mainly focused on their application in organic electronics. Recent works, however, show that due to the unique optical and photophysical properties of CPs, such as high absorption in UV-Vis or even near-infrared (NIR) region and efficient intra-/intermolecular energy transfer, which can be relatively easily optimized, CPs can be considered as an effective light-activated source of versatile and highly reactive singlet oxygen for medical or catalytic use. The aim of this short review is to present the novel possibilities that lie dormant in those exceptional polymers with the extended system of $\pi$-conjugated bonds.
\end{abstract}

Keywords: conjugated polymers; conductive polymers; singlet oxygen; reactive oxygen species; photosensitizers; PDT; PACT

\section{Introduction}

Singlet oxygen, ${ }^{1} \mathrm{O}_{2}$, is one of the Reactive Oxygen Species (ROS), that has been under high research interest for more than 50 years now [1]. Molecular oxygen possesses two singlet excited states $\left(\mathrm{a}^{1} \Delta_{\mathrm{g}}\right.$ and $\left.\mathrm{b}^{1} \Sigma_{\mathrm{g}}+\right)$ that, unlike ground state triplet oxygen, do not have unpaired electrons on the $\pi$-antibonding orbital [1,2]. The $\mathrm{b}^{1} \Sigma_{\mathrm{g}}+$ form is highly unstable and rapidly decays to $\mathrm{a}^{1} \Delta_{\mathrm{g}}$. The latter, commonly named as singlet oxygen, is a relatively long-lived (45 min in gas phase and up to $10^{-3} \mathrm{~s}$ in solution) species, because the transition to ground triplet state, $\mathrm{X}^{3} \Sigma_{\mathrm{g}}{ }^{-}$, is spin-forbidden. Singlet oxygen has stronger oxidizing properties than triplet state molecular oxygen, which results in its higher reactivity and electrophilic character. Hence, it has become an interesting candidate for the application in various areas of medicine, chemistry or environmental science [1,2].

Among several methods of singlet oxygen formation, chemical and photochemical routes appear as the most prominent. The first one may consist of the decomposition of organic or inorganic oxygen-bearing species [3-5]. Even though attention nowadays is paid to development of the chemical methods, the photochemical approach for singlet oxygen generation still remains the most commonly applied. ${ }^{1} \mathrm{O}_{2}$, together with other forms of ROS, can be produced in the so-called photosensitization process, where the appropriate photoactive molecule, i.e., photosensitizer (PS), is excited from its ground state, $\mathrm{S}_{0}$, into singlet excited state, $S_{n}$, by light illumination. In the next steps, the relaxation (internal conversion, $I C$ ) of $S_{n}$ gives the sensitizer's lowest singlet excited state, and further, the triplet state with longer lifetime, $\mathrm{T}_{1}$, via the intersystem crossing (ISC). The photosensitizer being in the triplet state can further transfer its energy to ground state triplet oxygen to form a singlet oxygen molecule (see Jablonski Diagram, Figure 1) [1,2]. The excited photosensitizer can also react with other substrates by the electron transfer or hydrogen abstraction, to form radicals or radical ions that can subsequently react with triplet oxygen to form other ROS, such as the superoxide anion $[1,2,6]$.

Several review papers discussing the details of the chemical and physical properties of singlet oxygen, its generation, detection and application, have been published until now [1,2,6-9]. Hence, these issues will not be discussed further in this short review. This 
work aims to show new trends in the application of conjugated polymers (CPs) as efficient organic photosensitizers.

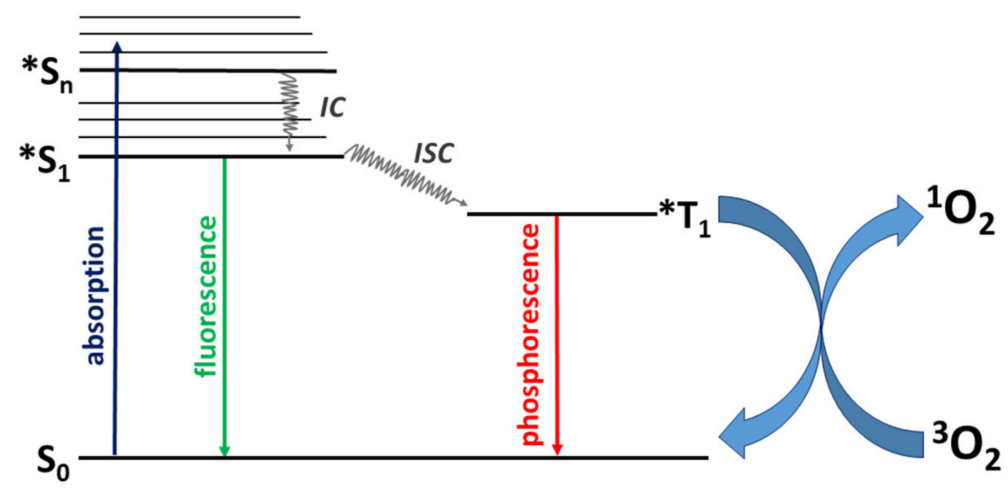

Figure 1. Jablonski diagram of the photosensitization process. $S_{0}$-singlet ground state of photosensitizer, ${ }^{*} S_{1, n}$-singlet excited states of photosensitizers, ${ }^{*} \mathrm{~T}_{1}$-triplet excited state of photosensitizer, IC-internal conversion, and ISC-intersystem crossing.

There are several requirements that should be fulfilled by a molecule to be considered as a good photosensitizer. First of all, it should possess a high absorption coefficient at the wavelength consistent with the illumination source. Second of all, the triplet state should be characterized by an energy higher than $95 \mathrm{~kJ} / \mathrm{mol}$ and long lifetime (more than $1 \mu \mathrm{s}$ ) to allow for the transfer of energy to triplet oxygen. Additionally, the triplet state of PS should be formed with a high quantum yield from the singlet state. Finally, photosensitizers should possess high photostability $[1,10]$. Moreover, for the medical applications PS must have low dark toxicity [11]. Among the classical photosensitizers, the following groups can be defined: (a) organic dyes and aromatic hydrocarbons, (e.g., rose bengal, methylene blue, anthracene), (b) porphyrins, phthalocyanines, (c) transition metals (e.g., ruthenium, platinum, palladium) complexes, and (d) inorganic semiconductors (e.g., $\mathrm{TiO}_{2}$, $\mathrm{ZnO})[1,12,13]$. They are very efficient in the photogeneration of singlet oxygen; however each of them possesses some weaknesses. For example, dyes are usually monochromophore molecules that have only one, usually narrow absorption band in the visible region, which in turn results in rather noneffective usage of the solar light. Another critical issue is the efficiency of the intersystem crossing process. Hence, the research for the perfect photosensitizer is still underway. It has been shown that the visible-light absorption can be significantly enhanced by the attachment of various light-harvesting antennas $([14,15])$, while ICS can be facilitated by the introduction of a heavy atom or by lowering of the energy difference between the $S_{1}$ and $T_{1}$ states. These approaches are accomplished in the novel triplet organic photosensitizer [16]. Moreover, other groups of compounds have been also proposed in recent years as efficient sources of singlet oxygen-e.g., pristine or functionalized carbon nanostructures (fullerenes, nanotubes, graphene oxide, graphene quantum dots) [17-22], or the already-mentioned conjugated polymers.

Since the pioneering work on conductive polyacetylene by MacDiarmid, Heeger, and Shirakawa [23], CPs have been mainly investigated for the application in organic electronics-e.g., in organic photovoltaics (OPVs), organic light-emitting diodes (OLEDs), organic field-effect transistors (OFETs), (bio)sensors, or batteries [24-26]. The formation of various ROS by conjugated polymers have been known for several years [27]; however, this phenomenon is rather undesirable in the key application of conducting polymers, organic electronics, since it may lead to the oxidative decomposition of the electroactive materials, and thus results in the lowering of the efficiency of the device [28-31]. Still, what is unfavorable for organic electronic devices appears to be attractive for the biological or photocatalytic applications. Several features make CPs attractive candidates for the generation or detection of singlet oxygen [32]. They are generally characterized by the high absorption in UV-Vis or even near-infrared (NIR) region and an efficient energy 
transfer [33,34]. Moreover, it has been shown that the energy levels of the $S_{n}$ and $T_{n}$ states, and thus the ISC process [35], can be optimized by increasing the number of conjugated units, which is the basis of so-called "polymerization-enhanced photosensitization" concept $[16,36,37]$. Conjugated oligomers/polymers can be applied in the photosensitization of ${ }^{1} \mathrm{O}_{2}$ either acting as photosensitizer itself or acting as the light-harvesting antennas or backbone to other PS molecules (e.g., dyes, fullerenes) [34,38,39]. In this review paper, the examples of both types of $\mathrm{CP}$-based photosensitizers used in the medical applications, fine chemical synthesis or wastewater treatment-will be discussed.

\section{Conjugated Polymers as ${ }^{1} \mathrm{O}_{2}$ Source in Medical Applications}

\subsection{Photodynamic Therapy (PDT)}

Conjugated polymers have received a lot of attention in medical research, due to their good biocompatibility, photostability, relatively easy functionalization, and tunable optical properties. They have been widely studied for the application in imaging (e.g., fluorescence imaging, photoacoustic imaging), regulation of cell activity (e.g., gene expression, enzyme action) and light-activated therapies mainly based on the ROS activity [40-43]. Reactive oxygen species, including singlet oxygen, commonly occur in biological systems, and they are vital participant in the functioning of the living organisms-e.g., taking part in cell signaling and apoptosis. However, the high concentration of ROS may lead to the oxidative damage of various biomolecules, such as DNA, proteins, which may cause carcinogenesis or age-related diseases. Their origin may be both exo- or endogenous, e.g., they can be produced by UV radiation, but also during the cellular respiration in mitochondria. In the normal cells, the ROS concentration and action are properly balanced, but in cancer cells the level of ROS is significantly higher because of the uncontrolled proliferation, which allows for the imaging of tumor cells. Importantly, cancer cells are typically more sensitive to ROS because of their less effective self-protection [44,45], and hence can be effectively destroyed by ${ }^{1} \mathrm{O}_{2}$, etc.

Until now, cancer therapies have mainly included surgery, chemotherapy or radiotherapy. In comparison to them, Photodynamic Therapy (PDT) possesses several advantages, such as higher selectivity, limited interaction with the healthy tissues and consequently reduced number of side effects $[10,46]$. In PDT, the photosensitizer molecule is introduced into patient's body and accumulates in the cancer cells. In the next step, PS is activated by the light irradiation with an appropriate wavelength to produce ROS via type I or type II mechanisms. Usually, PDT consists of multiple mechanisms leading to apoptosis or necrosis [34,45,47].

Several factors have to be considered when designing PDT agents. First of all, while PS molecules circulate within the bloodstream, singlet oxygen can also be produced, which would also damage the healthy cells. In order to reduce the side effects and minimize the damage of the normal tissues, the generation of ${ }^{1} \mathrm{O}_{2}$ should be precise and controllable. This can be achieved by introduction of $\mathrm{pH}-$-, polarity- or wavelength-sensitive systems [48,49]. Since PDT cancer therapy is based on the light-activated process, the penetration of light through tissues has to be considered. The photons in the UV-Vis range are characterized by rather low penetration depths (up to $2.5 \mathrm{~mm}$ ), while the ones in the near-infrared (NIR) region can penetrate up to $1 \mathrm{~cm}$ in tissues. The latter is also reasonably safe to the patient, since it is characterized by minimal phototoxicity [40]. Most of the classical photosensitizers absorb mainly in the range up to $700 \mathrm{~nm}$, like the clinically approved porphyrin-based PDT agents-e.g., photofrins have weak absorbance above $630 \mathrm{~nm}$ [50]. Additionally, many organic PSs are strongly hydrophobic, so that their in vivo application in the PDT is limited [51]. Hence, high attention is paid to the new photoactive systems that could overcome the above-mentioned issues.

One of the proposed solutions is the employment of conjugated polymers in PDT therapy. They possess the extended $\pi$-conjugation and thus efficiently absorb light in the NIR region, and have high rates of intersystem crossing to triplet states. This, among other things, renders them as promising candidates for the next generation of photosensitizers. 
The main limitation in application of CPs in biological systems is their highly hydrophobic characters, but this may be overcome by introduction of the polar or ionic side groups that strongly enhance the solubility of such macromolecules in water [52-54]. When the cationic or anionic groups are introduced into $\mathrm{CP}$ structures, conjugated polyelectrolytes are formed [55]. Conjugated polymers are commonly in the form of nanoparticles in PDT (conjugated polymer nanoparticles (CPNs)) [34,56,57], which can be produced directly during polymerization, under polymerization in micro-/miniemulsions, dispersion polymerization or emulsion polymerization, or after polymerization (postpolymerization strategy), with nanoprecipitation, micro-/miniemulsification or self-assembly processes [58]. Such CPNs usually contain surfactant chains that increase the stability and limit the aggregation in a water solution. Lately, two-photon photodynamic therapy (2PE-PDT) applying conjugated polymers is becoming the promising alternative, thanks to its high spatial resolution and deeper light penetration compared to the classical 1PE-PDT, which may be beneficial for treatment of, e.g., subcutaneous tumors or brain tumors. In this method, the upper excited singlet state of photosensitizers is produced by the absorption of two photons with lower energies. The transition goes via the so-called virtual state. The classical PSs are usually characterized by low two-photon absorption (TPA) cross sections, causing the $2 \mathrm{PE}$ process to be ineffective. Therefore, the research is carried out on the application of conjugated polymers (with significantly larger TPA cross section) in 2PE-PDT. Lately, it has been shown that the increase in the conjugation may cause the significant increase in the 2PA cross-section, thus making CPs attractive candidates for the 2PE-PDT strategy [59]. In one-photon and in two-photon PDT approaches, CPs can be applied either in the pristine form (acting as a photosensitizer itself) or in combination with the classical photosensitizers, such as porphyrins $[6,60]$. In the latter case, the conjugated polymers act as carriers and/or additionally as the light-harvesting antennas that, thanks to the energy transfer to PS, significantly boost the efficiency of singlet oxygen photogeneration. The energy transfer from the $\pi$-conjugated backbone to photosensitizer unit may occur via Förster resonance energy transfer (FRET) or bioluminescence energy transfer (BRET) [61].

The PDT agents consisting of the CPs acting as a PS can be, first of all, obtained by the formation of the two-dimensional system of the covalently bound classical $\pi$-conjugated photosensitizers, such as porphyrins. This coupling can be achieved by, e.g., Yamamoto Ullmann cross-coupling, as shown in Figure 2A. The consecutive sulfonation enhances dispersion in water. The resulting $\mathrm{CP}$-based photosensitizer possesses strong absorbance up to $1100 \mathrm{~nm}$, i.e., the region of light that penetrates through tissues, contrary to the monomer that absorbs mainly in the UV-Vis region (Figure 2B) [50].

Next to the dye-based CPs, other $\pi$-conjugated building blocks have been reported as promising for the light-induced therapy. Let us first consider systems in which $\mathrm{CP}$ acts as a carrier and light-harvesting antenna for the classical PSs. The noncovalent incorporation of the PS molecule inside CPNs can be achieved thanks to the hydrophobic interactions or electrostatic interactions, leading to the encapsulation of the PS's molecules inside the CPs nanoparticles [33]. Various polyfluorene-based polymers, such as poly[(9,9dioctylfluorenyl-2,7-diyl)-alt-co-(1,4-benzo- $\left\{2,1^{\prime}, 3\right\}$-thiadiazole)] (PFBT), poly[ $\{9,9$-dioctyl2,7-divinylene-fluorenylene\}-alt-co-\{2-methoxy-5-(2-ethylhexyloxy)-1,4-phenyl-ene\}] (PFPV), poly[9,9-dibromohexylfluorene-2,7-ylenethylene-alt-1,4-(2,5-dimethoxy) phenylene] (PFEMO) (Figure 3) or poly\{9,9-bis[6"-(bromohexyl)-fluorene-2,7-ylenevinylene]-co-alt-1,4-(2,5-dicyanophenylene)\} (PFVCN), have been reported as supports for the porphyrin photosensitizers, significantly increasing the efficiency of ${ }^{1} \mathrm{O}_{2}$ generation under one- or two-photon excitation [53,62-64]. In the case of TPP-PFBT system, almost 100\% efficient energy transfer was observed and nearly $50 \%$ quantum yield of ${ }^{1} \mathrm{O}_{2}$ production [53]. A similar quantum efficiency was also reported for the other polyfluorenes. The exemplary system for the 2PE-PDT consisting of TPP photosensitizer and PFEMO as light-harvesting antenna is given in Figure 4. As shown in Figure 4b, the emission spectra of PFEMO nicely overlaps with the absorption bands of TPP photosensitizer. When the one-photon emission spectra of nanoparticles with or without PFEMO are compared (Figure 5a), one can easily see that 
the intensity of the TPP emission at ca. $650 \mathrm{~nm}$ is significantly boosted when polyfluorene is present, which confirms the energy transfer from PFEMO to TPP. Under two-photon excitation (Figure $5 b$ ) the nanoparticles without PFEMO show only weak emission, because TPA of porphyrin is relatively low, but it is about 20-times larger in the polyfluorenecontaining CPNs [63]. Considering the polyfluorenes as light-harvesting antennas for the 2PE-PDT, it has been shown that the value of TPA can be significantly boosted by introduction of ethynylene or vinylene groups and even more by the incorporation of the electron withdrawing cyano groups [65].

\section{A}
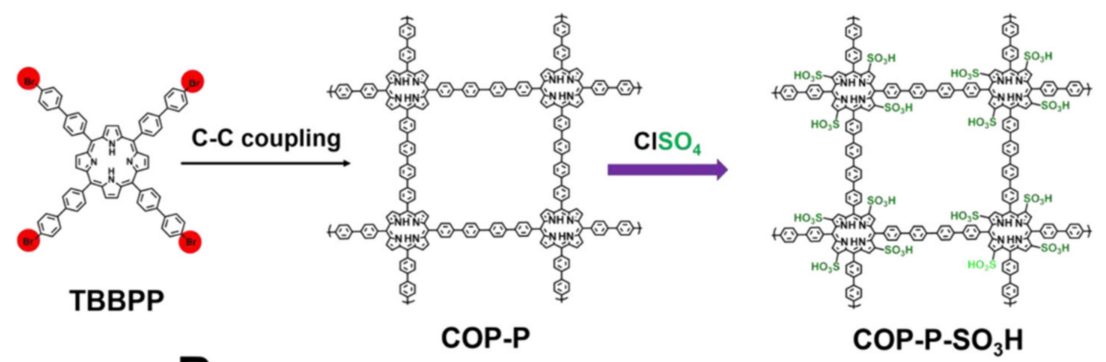

B

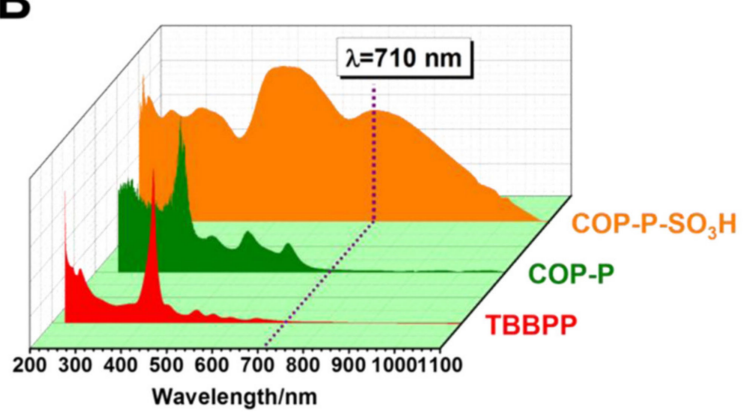

Figure 2. (A) Strategy for the formation of the two-dimensional porphyrin-based conjugated polymer for photodynamic therapy; (B) UV-Vis spectra of the aqueous solution of substrate and products. Reprinted with permission from [50]. Copyright (2016) American Chemical Society.
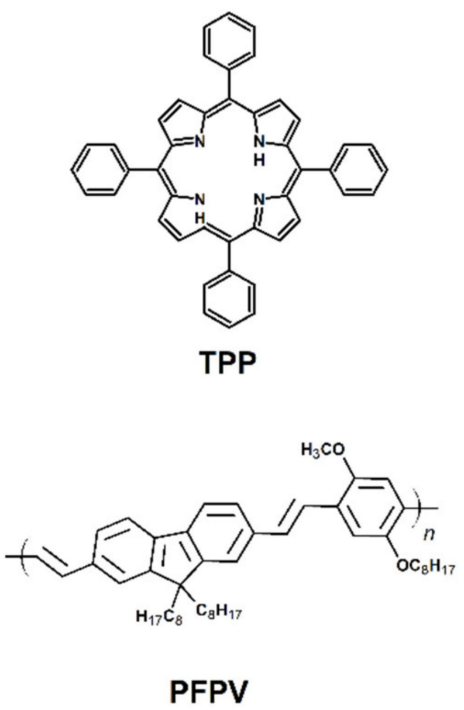<smiles>Cc1ccc2c(c1)C(C)(C)c1cc(-c3ccccc3-c3ccccc3)ccc1-2</smiles>

PFBT

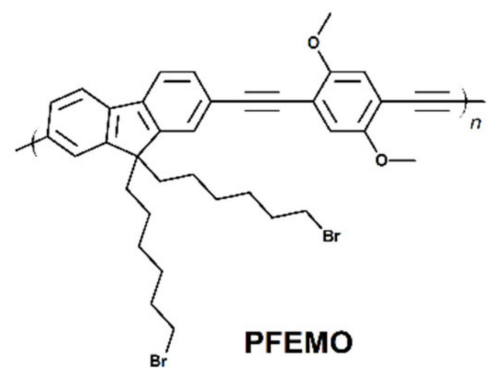

Figure 3. Chemical structure of TPP and fluorene-based polymers (poly[(9,9-dioctylfluorenyl2,7-diyl)-alt-co-(1,4-benzo- $\left\{2,1^{\prime}, 3\right\}$-thiadiazole)] (PFBT) and poly[9,9-dibromohexylfluorene-2,7ylenethylene-alt-1,4-(2,5-dimethoxy) phenylene] (PFEMO) (PFEMO), investigated in [53,62,63], respectively) used to obtained conjugated polymers nanoparticles for photodynamic therapy. 


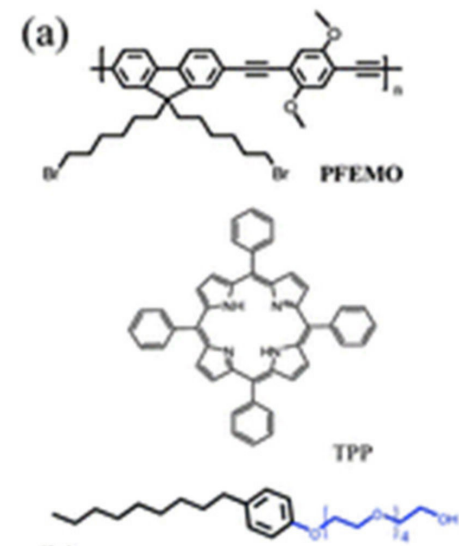

(b)

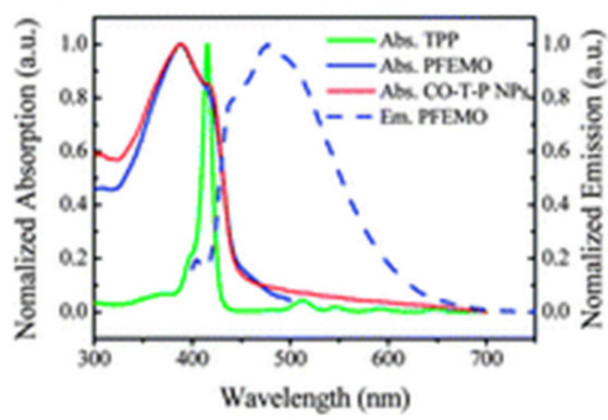

Two-photon

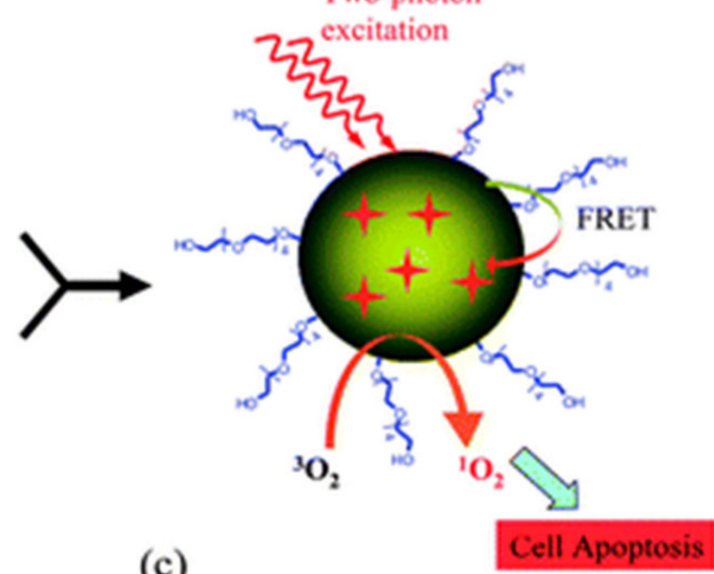

(c)

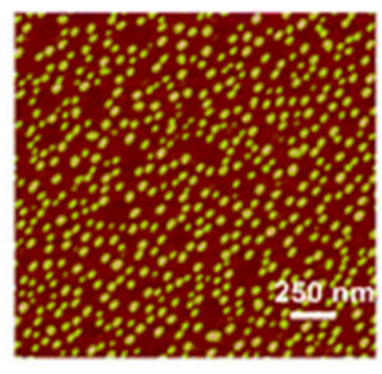

Figure 4. (a) Scheme of the formation of conjugated polymer nanoparticles (CPNs) for two-photon photodynamic therapy (two-photon Photodynamic Therapy (2PE-PDT)), (b) normalized absorption spectra of TPP, PFEMO and resulting CPNs (solid lines), and emission spectra of PFEMO (dashed line), (c) AFM imaging of CPNs on a mica substation. Republished with permission of The Royal Society of Chemistry from [63]; permission conveyed through Copyright Clearance Center Inc.
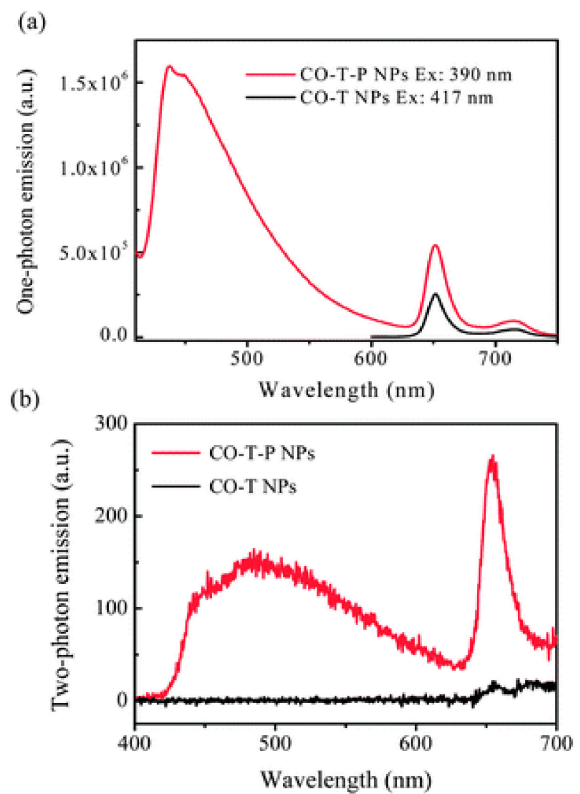

Figure 5. (a) Emission spectra of CPNs with or without PFEMO under excitation at their individual absorption maximum (390 nm for CO-T-P NPs and $417 \mathrm{~nm}$ for CO-T NPs); (b) comparison of emission spectra of CPNs with or without PFEMO under two-photon excitation at $800 \mathrm{~nm}$. Republished with permission of The Royal Society of Chemistry from [63]; permission conveyed through Copyright Clearance Center Inc. 
The polyfluorene-vinylene-phenylene-based conjugated polyelectrolyte can act itself as a source of ROS in 2PE-PDT. Similarly to the TPP-containing systems, the presence of the $-\mathrm{CN}$ groups attached to the phenyl ring causes a significant increase in the two-photon cross section area and the quantum yield of singlet oxygen photogeneration [66].

Interestingly, when the above-mentioned energy transfer from the light-harvesting chain to PS is incomplete, the double action is possible-the imaging/detection of the cancer cells and the photodynamic action against them, as shown for the polythiophene-porphyrin dyad [54] or iridium (III) complex with covalently attached polyfluorene units. With such $\pi$-conjugated systems the imaging guided PDT can be carried out [67], and it can be even more effective when CPNs with additional red-emitting dye components are used [68].

Though, the noncovalent doping of PSs inside CPNs is usually rather straightforward, it may result in the lowered efficiency of ${ }^{1} \mathrm{O}_{2}$ photogeneration (because of the aggregation of PS inside nanoparticles) or uncontrolled leakage of PS molecules [51]. Alternatively, the photosensitizer units can be covalently attached to the conjugated polymers either as a pendant group or incorporated in the main chain $[33,49,51]$. Jiang et al. have recently reported the semiconducting polymer nanoparticles (Figure 6) consisting in the polyfluorene backbone with covalently attached iridium (III) complex and, additionally, boron dipyrromethene (BODIPY) units acting as the energy donors in the FRET process. The application of two luminophores resulted in a very high quantum yield of singlet oxygen photogeneration. Moreover, such CPNs allow for the mapping of the oxygen levels, thanks to the quenching of the phosphorescence of Ir (III) complex [49].

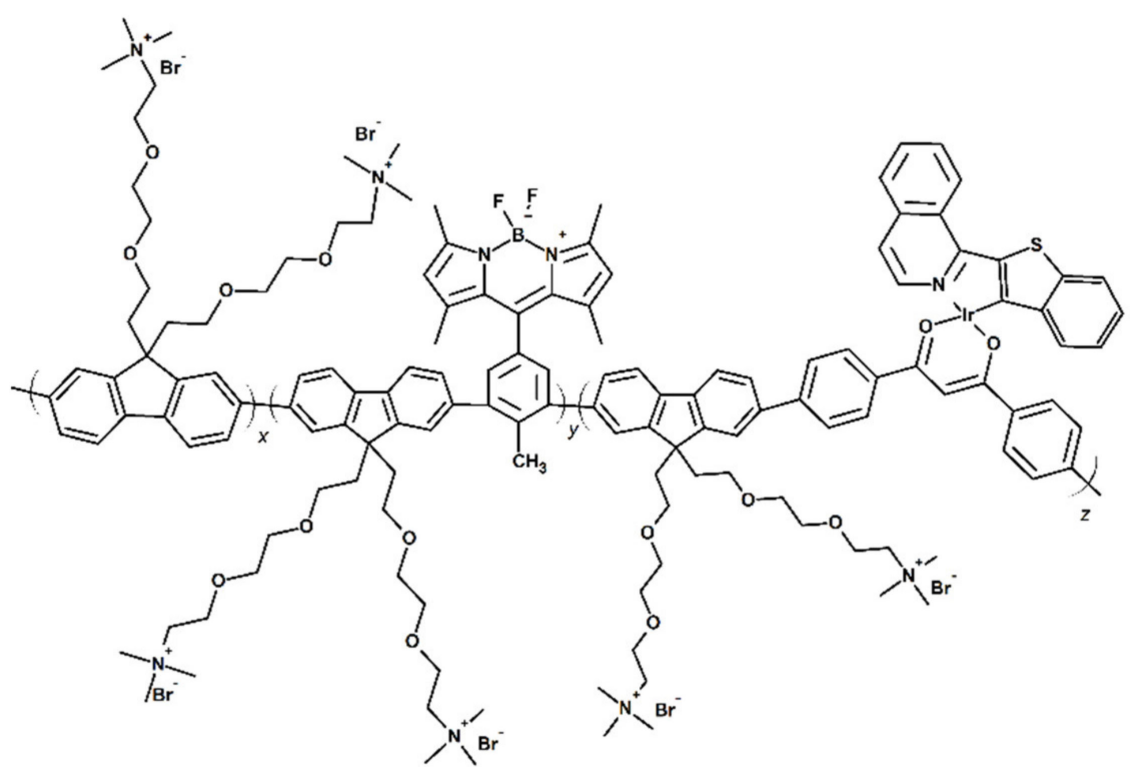

Figure 6. Schematic representation of the polyfluorene-based conjugated polymer with covalently attached Ir (III) complex and BODPIY units (investigated in [49]).

The conjugated polymers can act in a versatile manner in the biological systems. Upon irradiation they can form singlet oxygen for photodynamic therapy [56], but can also show NIR light-induced photothermal action against cancer cells $[40,51]$. This versatility of CPs is the basis for the development of the complex multifunctional systems for the anticancer therapy. First of all, if properly designed, CPs can act not only as PSs, but also as a platform for carrying other therapeutic agents such as small interfering RNA (siRNA) [69]. Second of all, when the semiconducting polymer nanomaterials are introduced into a patient's body, the production of ${ }^{1} \mathrm{O}_{2}$ molecule (and thus consumption of ${ }^{3} \mathrm{O}_{2}$ ) may also cause the selective cleavage of the linkers within PDT agent, resulting in the release of other therapeutic molecule (e.g., enzyme or drug). This cleavage can be induced either by singlet oxygen, as in the case of $-\mathrm{CH}_{2}-\mathrm{S}-\mathrm{C}\left(\mathrm{CH}_{3}\right)_{2}-\mathrm{S}-\mathrm{CH}_{2}-$ or $-\mathrm{S}-\mathrm{CH}=\mathrm{CH}-\mathrm{S}-$, or initiated by the local hypoxia. Such remote activation approach, presented by, e.g., $\mathrm{Li}$ and $\mathrm{Pu}$, can initiate local 
chemotherapy resulting in, e.g., DNA damage [40]. It has been reported that self-assembled CPNs consisting of poly(cyclopentadithiophene-alt-benzothiadiazole) grafted with PEG and bromoisophosphoramide mustard intermediates as chemodrugs can present double action when activated by NIR light-i.e., generation of singlet oxygen, and the release of the chemodrug upon hypoxia-cleavage of the linker [40].

In the third case, when Photothermal therapy (PTT) is considered, the additional effects relying on the conversion of light into thermal energy may occur and may result in the ablation and death of the cancer cells. The combination of two types of conjugated polymers into one nanoparticle may give rise to the synergistic therapeutic action of PDT and PTT against tumors. This approach was shown in the work of Feng et al., which describes (1) a fluorene-benzothiadiazole-based polymer and (2) a thiophene-thiadiazoloquinoxaline-based polymer, acting as PDT and PTT agents, respectively [70]. The resulting CPN showed a double effect against cancer cells, thanks to the significant yield of singlet oxygen photogeneration and high light-to-heat conversion.

Finally, it has to be remembered that the oxygen level is one of the key factors that has be taken into account in PDT, since its lower value may significantly limit the production of singlet oxygen and thus the efficiency of the whole PDT process. Li et al. proposed an attractive solution for this issue, based on the application of photosensitizers containing dimethylnaphthalene units acting as the singlet oxygen carriers. The ${ }^{1} \mathrm{O}_{2}$ molecules are further released in the tumor cells thanks to the NIR-activated photothermal effect (Figure 7) [71].

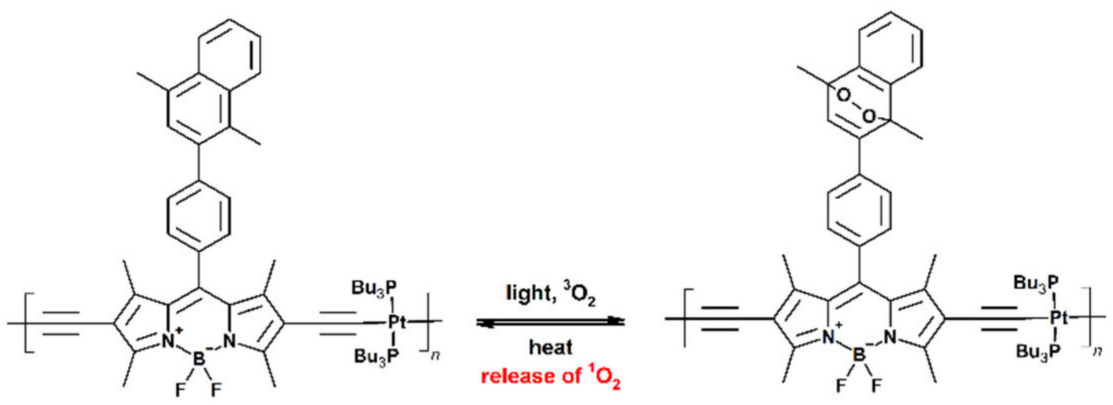

Figure 7. Schematic representation of PDT agent with ${ }^{1} \mathrm{O}_{2}$-carrier units (investigated in [71]).

\subsection{Photodynamic Antimicrobial Chemotherapy (PACT)}

The rapid increase in the number of antibiotic-resistant pathogens has initiated the process of searching for new, nonantibiotic methods of action against microbes. Here, reactive oxygen species, especially singlet oxygen, appear to be promising candidates, since they show high effectiveness against bacteria, viruses and fungi. This antimicrobial character of ROS was the background for the development of photodynamic antimicrobial chemotherapy (PACT). ROS action against microorganisms is nonselective and highly effective. Since they attack microbes in a versatile manner, there is rather small possibility of development of the microbes' resistance, which is extremely important from an epidemiological point of view $[47,72,73]$. One of the possible applications of the biocidal properties of ROS is in light-activated antimicrobial coatings, which has received high research interest in recent years $[11,74,75]$. In this case, it is more favorable to have a photosensitizer to absorb in the visible region so that the solar or conventional indoor light are efficiently used in PACT action.

As in the case of PDT therapy, CPs for the PACT application can act as a lightharvesting support for the common photosensitizers, not producing ROS themselves. In the work of Xing et al., the polythiophene-porphyrin system was formed based on the electrostatic interactions between an anionic $\mathrm{CP}$ backbone and positively charged porphyrin, and it showed light-activated antimicrobial action (Figure 8a,b). Although the covalent bond between units is not formed, still the energy transfer from the visible light-absorbing polythiophene enhances the production of singlet oxygen in the action 
against Escherichia coli (E. coli) under white light irradiation compared to the experiment in which only porphyrin is light-activated (Figure $8 \mathrm{c}$ ). The efficiency of the biocidal action increases up to certain extent with the increase in porphyrin concentration (Figure 8d) [76].
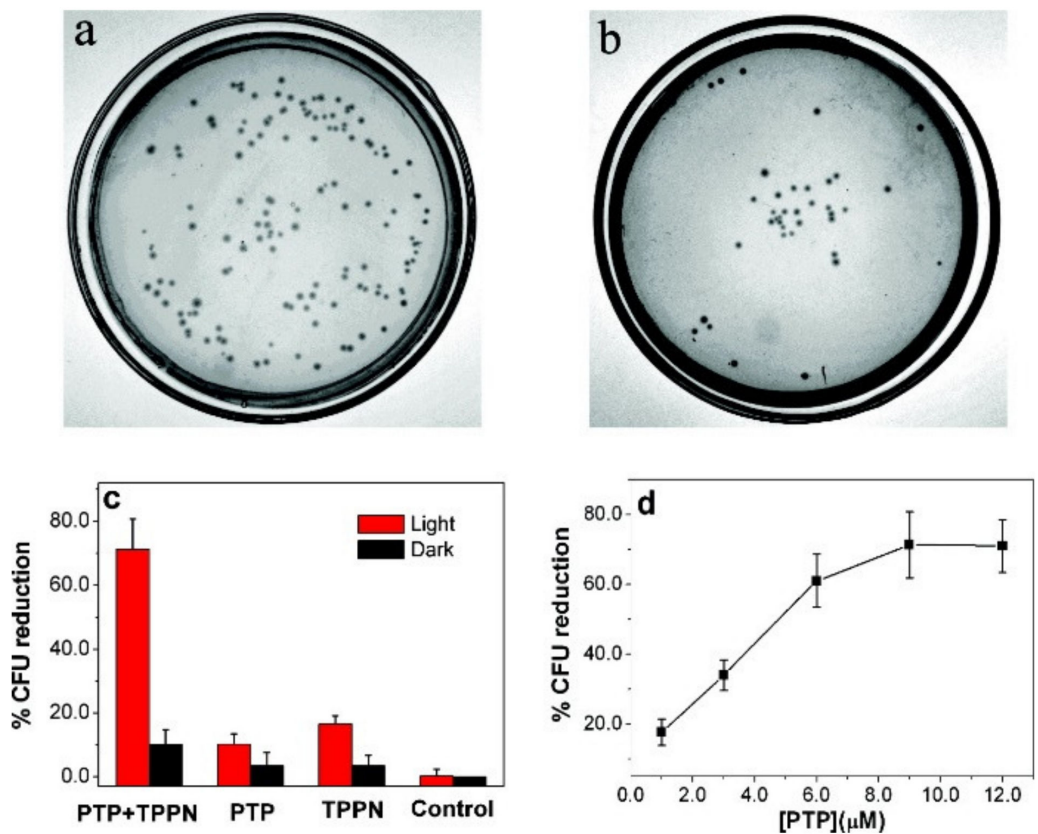

Figure 8. (a) Number of colony forming units (cfus) of Escherichia coli (E. coli) for control without photosensitizer in dark; (b) Cfu of E. coli suspension incubated with PTP/TPPN and irradiated with white light; (c) biocidal activities of PTP/TPPN, PTP, and TPPN toward E. coli in the dark and under white-light illumination for $5 \mathrm{~min}$. (d) Reduction in cell viability of PTP/TPPN complex toward E. coli as a function of PTP concentration. Reprinted with permission from [76]. Copyright (2009) American Chemical Society.

The possibility of the use of (cationic) conjugated oligomers or polymers in PACT as the main source of ROS has attracted considerable attention in recent years [77-79]. The lightinduced biocidal action of singlet oxygen and other types of ROS may be further boosted by the presence of the cationic groups in CPs, such as pendant quaternary ammonium units or cationic imidazolium groups in the main chain [80]. Such positively charged parts interact with the negatively charged bacteria membranes, which in turn allows for the more efficient antibacterial response both in dark and under light [81-83]. The mechanism of action of the conjugated oligomers/polymers against Gram-positive and Gram-negative bacteria has been widely discussed in the works of Wang et al. [84,85]. The dark- and light-initiated bactericidal actions were investigated with cationic-conjugated oligo- or polyelectrolytes based on phenylene ethynylene. Due to the structural differences of Gram-negative and Gram-positive bacteria, significant differences were observed in the bactericidal mechanism. Moreover, the mechanism also differs between polymeric and oligomeric agents. Considering the dark activity, in the case of the Gram-negative bacteria, the high molecular weight CPs act only on the bacterial cell surface, while oligomers can cause damage also to the cytoplasm. The thicker cell envelope of Gram-positive bacteria is, however, resistant towards penetration of both cationic poly- and oligo-CPs. It has been shown that singlet oxygen and the follow-up ROS cause the damage to the cell wall of the Gram-positive bacteria, while with the Gram-negative one they act on the cell wall and cellular components, such as DNA or proteins.

Among the $\pi$-conjugated monomers, benzothiadiazole (BT) is one of the most commonly used in PACT as a source of singlet oxygen in the donor-acceptor systems. For example, it has been shown that molecular doping of the thiophene-based polymer nanoparticles with an electron withdrawing BT group results in the improved photoinactivation of E. coli 
and Bacillus subtilis (B. subtilis). Importantly, the reported nanoparticles exhibited high stability and reusability [86]. Similar effect of enhancement of antimicrobial properties was observed when benzothiadiazole was introduced into the main chain of tetraphenylethenecontaining [87] or fluorene-co-phenylene-based conjugated polymers [88] (Figure 9A, B respectively). The first system showed high effectiveness against Staphylococcus aureus (S. aureus), while leaving mammalian cells unaffected, while the latter was effective even against ampicillin-resistant E. coli.

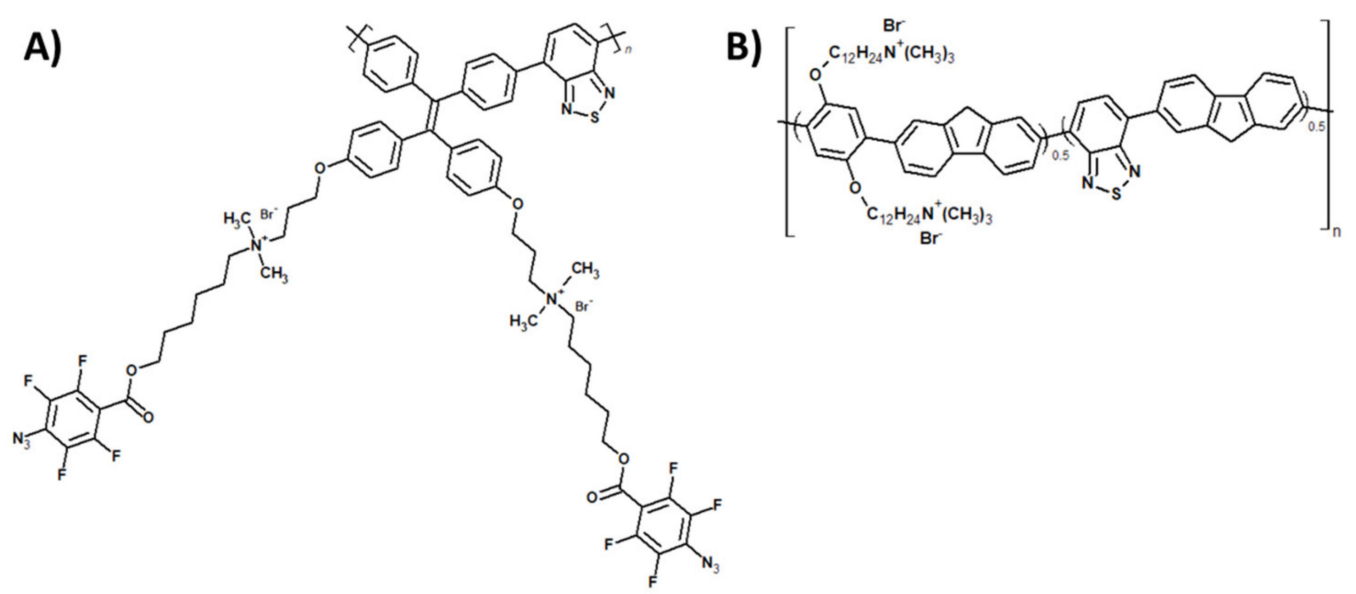

Figure 9. (A) Tetraphenylethene- and (B) fluorene-co-phenylene-based conjugated polymers with benzothiadiazole units, applied as Photodynamic Antimicrobial Chemotherapy (PACT) agents (investigated in $[87,88]$, respectively).

The possibility of the application of conjugated polymers in the photoinactivation of fungi has also been investigated. Xing et al. reported that the polythiophene-porphyrin system may be effectively used against Aspergillus niger [89], while very recently, Jagadesan et al. have shown that water-soluble imidazolium-containing cationic conjugated polymers exhibit high light-activated antifungal properties against Candida albicans [90]. In both cases, the presence of the cationic units allows for the electrostatic interactions of the CPs with the fungal cell wall, as in the case of bacteria, which in turn enhances the diffusion of ROS into the cell membrane. Finally, the latest work of Monge et al. has shown that the phenylene ethynylene-based conjugated oligomers/polymers can be effectively applied against severe acute respiratory syndrome coronavirus 2 (SARS-CoV-2) with the reduction in the virus of up to 5-log within 5 min [91].

The tremendous development in the application of conjugated polymers in photodynamic action against cancer or various microbes has been observed in recent years. However, several unknowns have to be cleared and some issues, such as hydrophobicity, have to be resolved. Additionally, the strategy for the introduction of CP-based drugs into the body and their short-term and long-term safety to patients are critical for opening the doors for the actual application of CPs in light-activated therapies.

\section{Conjugated Polymers as ${ }^{1} \mathrm{O}_{2}$ Sources in Photo-Oxidation Processes}

As a strong oxidizing agent, singlet oxygen is considered as a valuable reagent in organic synthesis. To name a few, ${ }^{1} \mathrm{O}_{2}$ can be successfully applied in the Diels-Alder reaction with dienes to form endoperoxides, [2 + 2] cycloaddition reaction to olefins to form dioxetanes, synthesis of hydroperoxides from alkenes or phenols or the oxidation of sulfides to sulfoxides and phosphines to phosphine oxides $[1,7,8,92,93]$. This versatility makes singlet oxygen attractive not only in the synthesis of fine chemicals, but also for solar light-driven wastewater treatment [94]. In both cases, ROS species are considered as economically and environmentally friendly reagents $[95,96]$. Keeping in mind that the lifetime of singlet oxygen in the solution phase is very short, it has to be photogenerated in 
situ in the reaction mixture either by homogenous or heterogeneous sensitizers. Typically solid or solid-supported PSs show lower quantum efficiencies of ${ }^{1} \mathrm{O}_{2}$ production, but such an approach may be beneficial for the practical use taking into account the product separation, so as the recovery and reuse of the PS. Additionally, in many cases the solidsupported sensitizers showed higher photostability than the counterparts in the solution phase $[1,7,8,97,98]$. While considering photocatalytic processes employing light-activated conjugated polymers, care has to be taken to properly identify the type of the reactive species $\left({ }^{1} \mathrm{O}_{2}, \mathrm{e}^{-}, \mathrm{H}_{2} \mathrm{O}_{2}\right.$, etc. $)$ being produced by the catalyst. This can be achieved by applying various specific traps and UV-Vis or EPR spectroscopies [99-103].

\subsection{Synthesis of Fine Chemicals}

Thanks to the above-mentioned properties, singlet oxygen has become one of the most widely studied reagents for the synthesis of the fine chemicals, allowing the obtention of various important building blocks of (bio) pharmaceuticals or agrochemicals. In this area, the conjugated microporous polymers (CMPs) have been under high research interest as potential heterogeneous catalysts for more than 10 years now. CMPs are amorphous materials consisting of the $\pi$-conjugated monomers covalently linked to form three-dimensional structures $[104,105]$. They are categorized as a subgroup of porous organic polymers (POPs) [106-108]. CMPs are characterized by the strong visible light absorbance resulting from the $\pi$-conjugated system and the microporous structure. These properties make them attractive for the visible light-driven photocatalysis either in batch or continuous-flow reactors [109]. The conjugated microporous polymers can consist of the classical photosensitizers, such as porphyrines or phthalocyanines, but structures such as thiophene, perylene or carbazole, commonly studied in the organic electronics, can also serve as CMPs' building blocks $[110,111]$. CMPs are obtained in numerous types of coupling or condensation reactions and the chosen synthetic methodology influences optical, redox and morphological properties of the catalyst [112]. From the morphological point of view, several parameters of CMPs have to be well-defined, such as the crystallographic structure characterized by X-ray Diffraction (XRD) or the pore size and the specific surface area that are typically investigated by, e.g., nitrogen sorption measurements (Figure 10). The latter are critical for the heterogeneous catalyst activity and the diffusion of reagents inside the pores and thus they strongly influence the overall efficiency of the photoprocess. Nevertheless, it has been shown that in the case of CMPs, their electronic structure, i.e., proper selection of donor and acceptor units, also plays a vital role in the photoactivity of the polymeric photosensitizers [113].

a)

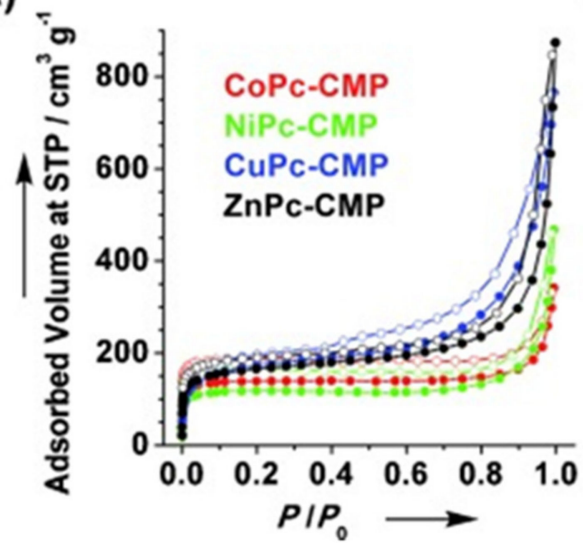

b) 'क

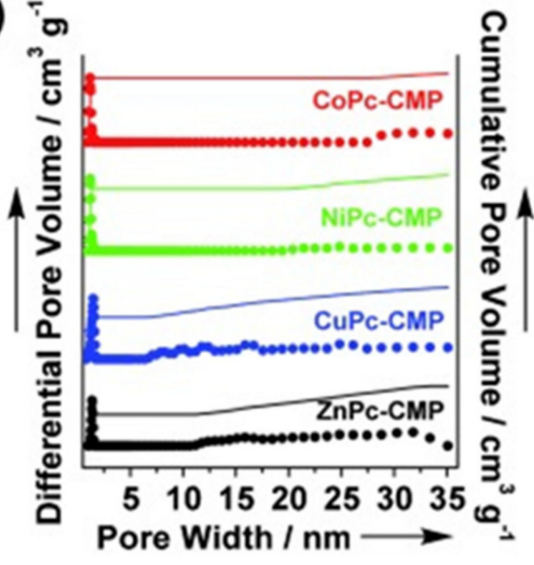

Figure 10. (a) Nitrogen sorption isotherms and (b) the profiles of the pore size distribution calculated with NLDFT method. Republished with permission of John Wiley \& Sons Inc. from [114]; permission conveyed through Copyright Clearance Center Inc. 
The CMPs based on phthalocyanines (Pcs) with cobalt, nickel, copper or zinc as the central metal can be synthesized in the polycondensation reaction of amino-substituted Pcs and terephthalaldehyde. The resulting photocatalysts possessed microporous structures and showed broadband absorbance in the Vis-NIR region. Zn- and Cu-containing CMPs showed high activity towards singlet oxygen photogeneration under illumination with $700 \mathrm{~nm}$ wavelength [114]. The same group has also shown that various linkers can be used to bind the phthalocyanines that allow for the further functionalization of CMPs structure [115]. Other work on the porphyrin-based CMPs showed their activity in the reaction with 9,10-diphenylanthracene [116], while porphyrin, porphyrin-co-phthalocyanine or subphthalocyanine microporous structures with the broadband absorbance up to 900 $\mathrm{nm}$ were reported as an efficient source of ${ }^{1} \mathrm{O}_{2}$ in the photo-oxidation of DPBF [117-119].

In the development of the conjugated microporous polymers, donor-acceptor (DA) systems have gained high interest. Such structures, with tunable photophysical and photochemical properties, can be obtained starting from the D-A dyad monomers [101]. Recently, Wu et al. described the three-step design of conjugated polymeric photosensitizers based on triphenylamine acting as a donor and fumaronitrile serving as an acceptor. The phenyl ring was additionally introduced into $\pi$-conjugated monomer structure (Figure 11A) to separate HOMO-LUMO and thus increase the efficiency of the ISC process and ${ }^{1} \mathrm{O}_{2}$ production. In the same manner, the corresponding polymer (Figure 11B) possesses higher photogeneration efficiency and broaden absorption. Finally, the crosslinking of the polymeric structure (Figure 11C) caused an increase in the porosity and specific surface area of the catalyst, simplifying separation and reuse. The versatility of the material was shown in the photo-oxidation processes and in the antimicrobial tests [120].

A)

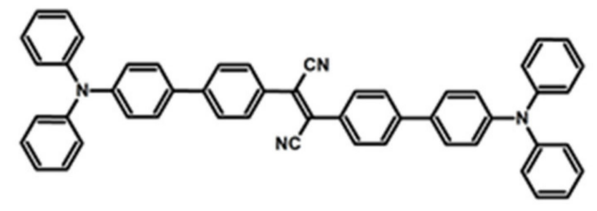

B)

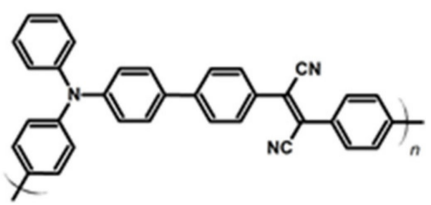

C)

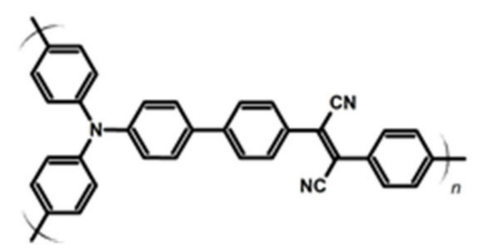

Figure 11. Schematic representation of CMPs based on triphenylamine and fumaronitrile with the increased conjugation lengths from (A-C) (investigated in [120]).

Another nitrogen-containing conjugated monomer, i.e., carbazole, has also shown promising photocatalytic activity for use as a CMP. The introduction of different linker groups, such as benzoselenadiazole or triazines, allows for the tuning of the photophysical and photochemical properties of the resulting catalysts. The reported D-A catalysts have high surface areas and good thermal and chemical stability. They were successfully applied in the light-activated oxidation of $\alpha$-terpinene to ascaridole, i.e., the anthelmintic drug, or thioanisole to methyl phenyl sulfoxide-i.e., a key intermediate in the synthesis of various pharmaceuticals such as nelfinavir. Moreover, the mentioned CMPs were effectively used in the degradation of mustard-gas simulant $[107,121]$.

The significant photocatalytic and photoredox activities of the benzothiadiazole and benzooxadiazole systems have been demonstrated in the number of visible-light-driven homogenous and heterogonous processes [96,122-127]. Zhang et al. have shown that poly (benzothiadiazole)-based CMPs can serve as ${ }^{1} \mathrm{O}_{2}$ sources in the oxidation of $\alpha$-terpinene to ascaridole. The photocatalytic process reached a $90 \%$ yield [128]. The introduction of the hydrophilic functional groups in the thiol-yne reaction with 3-mercaptopropionic acid 
resulted in CMPs easily forming a dispersion in water. Such CMPs were effectively applied in the oxidation of furoic acid under $400 \mathrm{~nm}$ irradiation to form 5-hydroxy-2 (5H)-furanone, which is key building block of various biologically active species, such as manoalide, a nonsteroidal anti-inflammatory agent [129].

It is well-known that boron dipyrromethene (BODIPY) itself is a very poor photosensitizer; however, it has been shown that the introduction of specific functional groups may lead to an increase in the triplet states probability in BODIPY, hence the increase in its efficiency of ${ }^{1} \mathrm{O}_{2}$ photogeneration [130-134]. Liras et al. presented a heavy-atom-free BODIPY-based CMP (Figure 12A) with a microporous structure and high surface area. The material was employed in the light-induced oxidation of thioanisole by singlet oxygen to form methyl phenyl sulfoxide. Compared to the corresponding homogenous catalysts, BODIPY-CMP showed a four-times higher reaction rate and simplified reuse [106]. BODIPY can also be combined with carbazole units (Figure 12B) to form a soluble porous polymeric source of ROS [135]. Tobin et al. also reported the application of the BODIPY-based CMPs in the commercial flow reactor for the photochemical oxidation of $\alpha$-terpinene with conversion reaching $99 \%$ after just $1 \mathrm{~h}$ [136].

A)

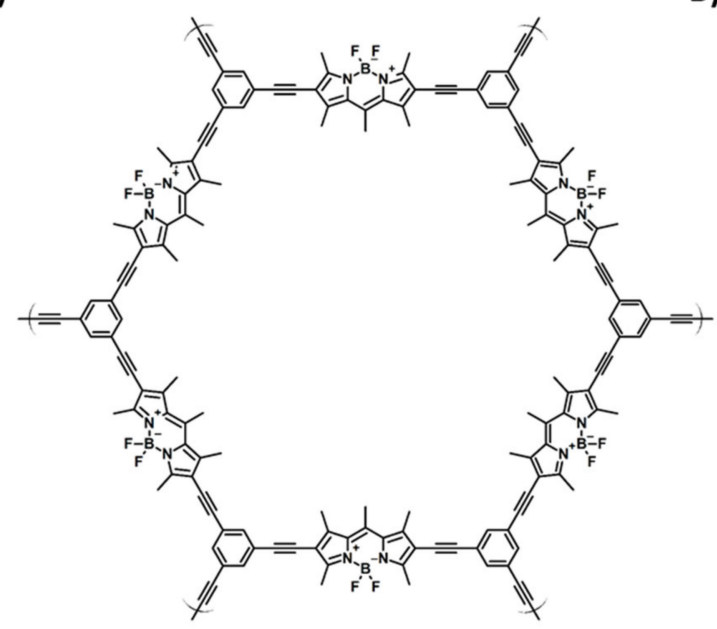

B)

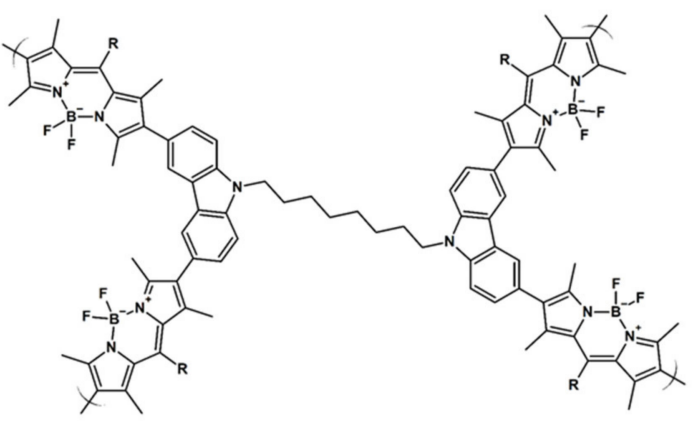

Figure 12. Schematic representation of CMPs based on boron dipyrromethene (BODIPY) with (A) 1,3,5-triethynylbenzene or (B) carbazole units (investigated in [106] and [135], respectively).

Next to CMPs, another strategy is to use CPs-based photocatalysts in the form of thin layers deposited on the solid support or free-standing nanosheets. In the first case, the layers of conjugated polymers can be formed on the solid support by, e.g., drop-casting, spin-coating or electrochemical polymerization. The glass-supported thin layers of CPs with perylene diimide units obtained by spin-coating were applied in the synthesis of ascaridole from $\alpha$-terpinene [137]. Moreover, the electrochemical polymerization was proposed as a straightforward process of deposition of the photoactive conjugated films containing phenothiazine and/or fullerene sensitizers [138-141]. Lately, Zhou et al. reported the polyimide nanosheets formed by combining the perylene core with triazine or heptazine blocks. The resulting conjugated polymer with the optimized $\pi-\pi$ stacking showed high photocatalytic activity in the oxidation of amines at room temperature. Both singlet oxygen and superoxide radical anions were identified as the dominant ROS present. The process resulted in the $99 \%$ conversion and $100 \%$ selectivity after $2 \mathrm{~h}$ with $\mathrm{N}$-benzyl benzaldimine as the final product [142].

\subsection{Wastewater Treatment}

The high oxidizing properties of singlet oxygen are also useful for the purification of industrial and urban wastewaters $[1,94]$. Studies in this area mainly focus on the removal of dyes-phenols occurring from, e.g., dye and paper industries-and sulfides, 
produced in, e.g., the food or petroleum industry, as well as water disinfection from various microorganisms.

Lately, Cui et al. described the CMPs based on the amine-bearing copper porphyrin with various linkers forming imine groups (Figure 13) obtained in microwave-assisted synthesis. The CMPs possessed large surface areas and strong absorptions from 300 up to $1000 \mathrm{~nm}$, and hence were effectively used as a source of $\operatorname{ROS}\left({ }^{1} \mathrm{O}_{2}, \mathrm{OH}\right.$ and $\left.\mathrm{O}_{2}{ }^{-}\right)$ in the degradation of model dyes from the wastewater. It has also been shown that the best photocatalytic properties were observed for the CMP containing $-\mathrm{OH}$ groups, which was assigned to the higher dispersity in water and more advantageous electronic structure, hence indicating that by careful design of the linker CMPs can strongly boost the performance of CMPs [143]. Recently, CMPs have also been effective as a light-activated sources of ROS in the degradation of antibiotics, such as fluoroquinolones [144].
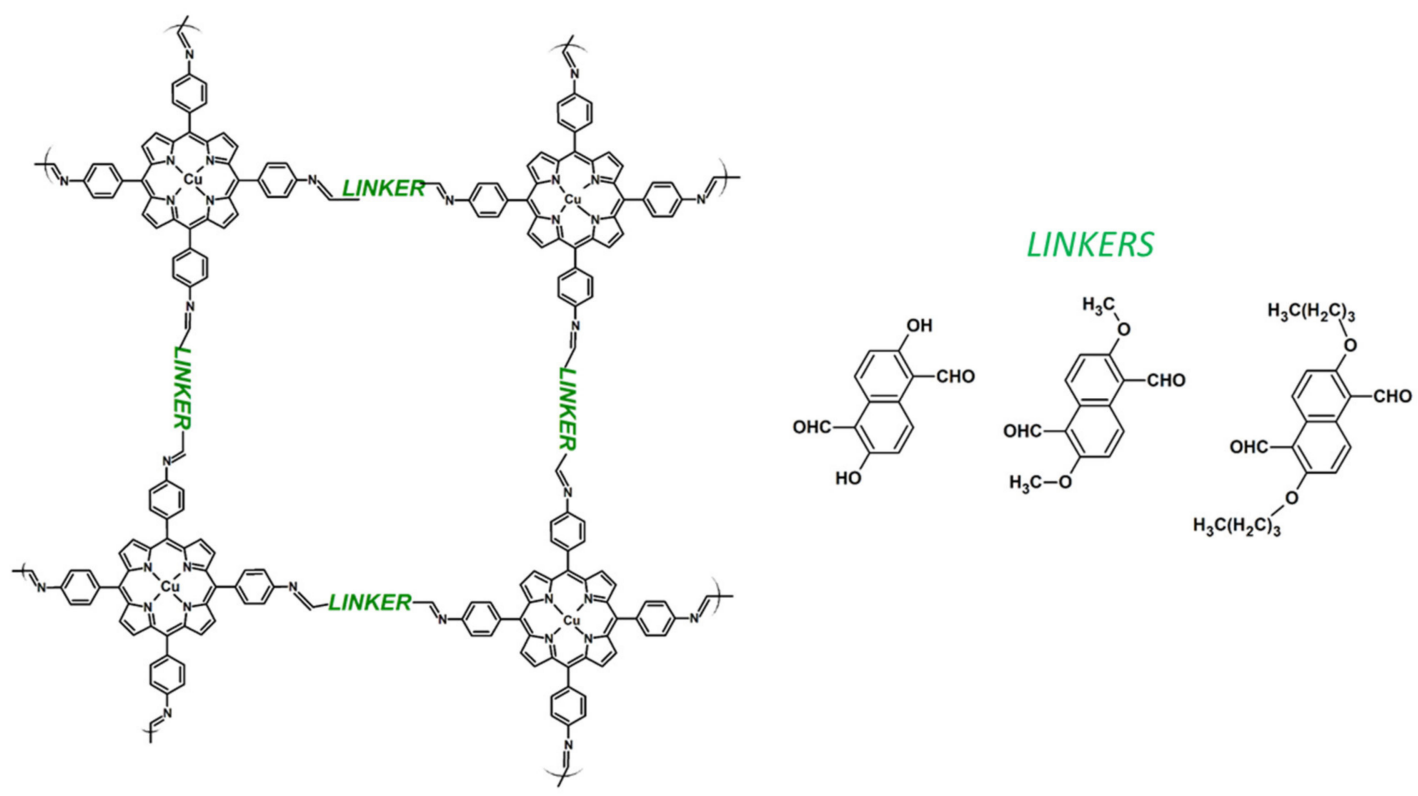

Figure 13. Schematic representation of copper porphyrin-based CMPs with various linkers (investigated in [143]).

Next to highly porous systems, the 2D- and the linear 1D-conjugated polymers can be also used in light-activated wastewater treatments. The thin layers of electrochemically polymerized phenothiazines showed to be effective in the degradation of the phenol from the aqueous solution under visible light illumination [145], while the dithienoarsolefluorene-based polymer [146] and 1D polyporphyrin-benzobisoxazole [147] were successfully applied as sources of singlet oxygen in the photodegradation of rhodamine-based dyes. Both CPs were active under visible-light irradiation, could be recycled, and showed high photocatalytic capabilities. Finally, Shen et al. have reported the application of the polyamide-supported benzothiadiazole (BT) photosensitizer in the degradation of bisphenol A and cimetidine and inactivation of cryptosporidium present in water solutions [148].

As shown, the tremendous development in the application of CMPs in photooxidation reactions has been reported in the recent years. The crystallinity, active surface area, chemical purity, and stability of such systems still need to be enhanced to make them competitive to other typically used photocatalysts. This is usually not an issue in the case of the approach based on the thin layers of CPs, but those, on the other hand, usually suffers from the lower overall efficiency of the photooxidation process due to inhibited contact of the reagents with the active surface. Such layers, however, may be advantageous for the application with the continuous-flow photoreactors. Nevertheless, in both forms of CPs more straightforward, environmentally friendly and easy scalable synthetic procedures need to be developed to allow for their industrial use. 


\section{Summary}

Based on the presented literature review, it can be stated that the conjugated polymers can be considered as very promising candidates for the next generation of photosensitizers. Thanks to their tunable and advantageous properties, they can meet the requirements to become highly efficient light-activated sources of singlet oxygen for either medical or catalytic purposes. However, a lot still has to be achieved before practical use starts. Above all, the extended (photo)stability of such systems has to be determined, since it has already appeared as a critical issue in the application of CPs in (opto)electronic devices. Nevertheless, as shown by the results of the works published before now, conjugated polymers might be an interesting alternative to classical photosensitizers and thus they deserve high attention and further investigation.

Funding: The author is grateful for the financial support from Silesian University of Technology, Poland under grant no. 04/040/RGH20/0141.

Institutional Review Board Statement: Not applicable.

Informed Consent Statement: Not applicable.

Conflicts of Interest: The author declares no conflict of interest.

\section{References}

1. DeRosa, M.C.; Crutchley, R.J. Photosensitized singlet oxygen and its applications. Coord. Chem. Rev. 2002, 233-234, 351-371. [CrossRef]

2. Ogilby, P.R. Singlet oxygen: There is indeed something new under the sun. Chem. Soc. Rev. 2010, 39, 3181-3209. [CrossRef] [PubMed]

3. Fudickar, W.; Linker, T. Release of Singlet Oxygen from Aromatic Endoperoxides by Chemical Triggers. Angewv. Chem. Int. Ed. 2018, 57, 12971-12975. [CrossRef]

4. Lu, C.; Zhang, C.; Wang, P.; Zhao, Y.; Yang, Y.; Wang, Y.; Yuan, H.; Qu, S.; Zhang, X.; Song, G.; et al. Light-free Generation of Singlet Oxygen through Manganese-Thiophene Nanosystems for $\mathrm{pH}$-Responsive Chemiluminescence Imaging and Tumor Therapy. Chem 2020, 6, 2314-2334. [CrossRef]

5. Kruk, I. Environmental Toxicology and Chemistry of Oxygen Species; Springer: Berlin/Heidelberg, Germany, 1998; ISBN 978-3-662$14779-5$.

6. Schmidt, R. Photosensitized Generation of Singlet Oxygen. Photochem. Photobiol. 2007, 82, 1161-1177. [CrossRef]

7. Wahlen, J.; de Vos, D.E.; Jacobs, P.A.; Alsters, P.L. Solid Materials as Sources for Synthetically Useful Singlet Oxygen. Adv. Synth. Catal. 2004, 346, 152-164. [CrossRef]

8. Ghogare, A.A.; Greer, A. Using Singlet Oxygen to Synthesize Natural Products and Drugs. Chem. Rev. 2016, 116, 9994-10034. [CrossRef] [PubMed]

9. Pibiri, I.; Buscemi, S.; Palumbo Piccionello, A.; Pace, A. Photochemically Produced Singlet Oxygen: Applications and Perspectives. ChemPhotoChem 2018, 2, 535-547. [CrossRef]

10. Callaghan, S.; Senge, M.O. The good, the bad, and the ugly-controlling singlet oxygen through design of photosensitizers and delivery systems for photodynamic therapy. Photochem. Photobiol. Sci. 2018, 17, 1490-1514. [CrossRef] [PubMed]

11. Noimark, S.; Dunnill, C.W.; Parkin, I.P. Shining light on materials-A self-sterilising revolution. Adv. Drug Deliv. Rev. 2013, 65, 570-580. [CrossRef]

12. Ishii, K. Functional singlet oxygen generators based on phthalocyanines. Coord. Chem. Rev. 2012, 256, 1556-1568. [CrossRef]

13. Imato, K.; Ohira, K.; Yamaguchi, M.; Enoki, T.; Ooyama, Y. Phenazine-based photosensitizers for singlet oxygen generation. Mater. Chem. Front. 2020, 4, 589-596. [CrossRef]

14. Zhao, J.; Wu, W.; Sun, J.; Guo, S. Triplet photosensitizers: From molecular design to applications. Chem. Soc. Rev. 2013, 42, 5323-5351. [CrossRef]

15. Cui, X.; Zhang, C.; Xu, K.; Zhao, J. Application of singlet energy transfer in triplet state formation: Broadband visible lightabsorbing triplet photosensitizers, molecular structure design, related photophysics and applications. J. Mater. Chem. C 2015, 3, 8735-8759. [CrossRef]

16. Zhang, G.; Zhang, D. New Photosensitizer Design Concept: Polymerization-Enhanced Photosensitization. Chem 2018, 4, 2013-2015. [CrossRef]

17. Stasheuski, A.S.; Galievsky, V.A.; Stupak, A.P.; Dzhagarov, B.M.; Choi, M.J; Chung, B.H.; Jeong, J.Y. Photophysical Properties and Singlet Oxygen Generation Efficiencies of Water-Soluble Fullerene Nanoparticles. Photochem. Photobiol. 2014, 90, 997-1003. [CrossRef] [PubMed]

18. Hamano, T.; Okuda, K.; Mashino, T.; Hirobe, M.; Arakane, K.; Ryu, A.; Mashiko, S.; Nagano, T. Singlet oxygen production from fullerene derivatives: Effect of sequential functionalization of the fullerene core. Chem. Commun. 1997, 21-22. [CrossRef] 
19. Gandra, N.; Chiu, P.L.; Li, W.; Anderson, Y.R.; Mitra, S.; He, H.; Gao, R. Photosensitized singlet oxygen production upon twophoton excitation of single-walled carbon nanotubes and their functionalized analogues. J. Phys. Chem. C 2009, 113, 5182-5185. [CrossRef]

20. Kholikov, K.; Ilhom, S.; Sajjad, M.; Smith, M.E.; Monroe, J.D.; San, O.; Er, A.O. Improved singlet oxygen generation and antimicrobial activity of sulphur-doped graphene quantum dots coupled with methylene blue for photodynamic therapy applications. Photodiagnosis Photodyn. Ther. 2018, 24,7-14. [CrossRef]

21. Jovanović, S.P.; Syrgiannis, Z.; Budimir, M.D.; Milivojević, D.D.; Jovanovic, D.J.; Pavlović, V.B.; Papan, J.M.; Bartenwerfer, M.; Mojsin, M.M.; Stevanović, M.J.; et al. Graphene quantum dots as singlet oxygen producer or radical quencher-The matter of functionalization with urea/thiourea. Mater. Sci. Eng. C 2020, 109, 110539. [CrossRef] [PubMed]

22. Peres, R.M.; Brêda, G.C.; Almeida, R.V.; Corrêa, R.J. Photochemistry of covalently bonded Graphene oxide-perylene diimide system for bacterial growth inhibition started by singlet oxygen. J. Photochem. Photobiol. A Chem. 2020, 407, 113058. [CrossRef]

23. Shirakawa, H.; Louis, E.J.; MacDiarmid, A.G.; Chiang, C.K.; Heeger, A.J. Synthesis of electrically conducting organic polymers: Halogen derivatives of polyacetylene, (CH)x. J. Chem. Soc. Chem. Commun. 1977, 578-580. [CrossRef]

24. Reynolds, J.R.; Thompson, B.C.; Skotheim, T.A. Conjugated Polymers: Perspective, Theory, and New Materials, 4th ed.; Taylor \& Francis: Abingdon, UK, 2019.

25. Lo, M.; Ktari, N.; Gningue-Sall, D.; Madani, A.; Aaron, S.E.; Aaron, J.-J.; Mekhalif, Z.; Delhalle, J.; Chehimi, M.M. Polypyrrole: A reactive and functional conductive polymer for the selective electrochemical detection of heavy metals in water. Emergent Mater. 2020, 3, 815-839. [CrossRef]

26. Slodek, A.; Zych, D.; Golba, S.; Zimosz, S.; Gnida, P.; Schab-Balcerzak, E. Dyes based on the D/A-acetylene linker-phenothiazine system for developing efficient dye-sensitized solar cells. J. Mater. Chem. C 2019, 7, 5830-5840. [CrossRef]

27. Fonseca, S.M.; Pina, J.; Arnaut, L.G.; de Melo, J.S.; Burrows, H.D.; Chattopadhyay, N.; Alcácer, L.; Charas, A.; Morgado, J.; Monkman, A.P.; et al. Triplet-state and singlet oxygen formation in fluorene-based alternating copolymers. J. Phys. Chem. B 2006, 110, 8278-8283. [CrossRef] [PubMed]

28. Scurlock, R.D.; Wang, B.; Ogilby, P.R.; Sheats, J.R.; Clough, R.L. Singlet Oxygen as a Reactive Intermediate in the Photodegradation of an Electroluminescent Polymer. J. Am. Chem. Soc. 1995, 117, 10194-10202. [CrossRef]

29. Cook, S.; Ohkita, H.; Durrant, J.R.; Kim, Y.; Benson-Smith, J.J.; Nelson, J.; Bradley, D.D.C. Singlet exciton transfer and fullerene triplet formation in polymer-fullerene blend films. Appl. Physic Lett. 2006, 89, 8-11. [CrossRef]

30. Bregnhøj, M.; Prete, M.; Turkovic, V.; Petersen, A.U. Oxygen-dependent photophysics and photochemistry of prototypical compounds for organic photovoltai. Methods Appl. Fluoresc. 2020, 8, 14001. [CrossRef] [PubMed]

31. Pacios, B.R.; Chatten, A.J.; Kawano, K.; Durrant, J.R.; Bradley, D.D.C.; Nelson, J. Effects of photo-oxidation on the Performance vinylene]:[6,6]-Phenyl C61-Butyric Acid Methyl Ester Solar Cells. Adv. Funct. Mater. 2006, 2117-2126. [CrossRef]

32. Frausto, F.; Thomas, S.W. Ratiometric Singlet Oxygen Detection in Water Using Acene-Doped Conjugated Polymer Nanoparticles. ACS Appl. Mater. Interfaces 2017, 9, 15768-15775. [CrossRef]

33. Sun, P.; Wang, G.; Hou, H.; Yuan, P.; Deng, W.; Wang, C.; Lu, X.; Fan, Q.; Huang, W. A water-soluble phosphorescent conjugated polymer brush for tumor-targeted photodynamic therapy. Polym. Chem. 2017, 8, 5836-5844. [CrossRef]

34. Meng, Z.; Hou, W.; Zhou, H.; Zhou, L.; Chen, H.; Wu, C. Therapeutic Considerations and Conjugated Polymer-Based Photosensitizers for Photodynamic Therapy. Macromol. Rapid Commun. 2018, 39, 1-15. [CrossRef] [PubMed]

35. Xu, S.; Yuan, Y.; Cai, X.; Zhang, C.J.; Hu, F.; Liang, J.; Zhang, G.; Zhang, D.; Liu, B. Tuning the singlet-triplet energy gap: A unique approach to efficient photosensitizers with aggregation-induced emission (AIE) characteristics. Chem. Sci. 2015, 6, 5824-5830. [CrossRef] [PubMed]

36. Wu, W.; Mao, D.; Xu, S.; Hu, K.F.; Li, X.; Kong, D.; Liu, B. Polymerization-Enhanced Photosensitization. Chem 2018, 4, $1937-1951$. [CrossRef]

37. Sun, X.; Wang, X.; Li, X.; Ge, J.; Zhang, Q.; Jiang, J.; Zhang, G. Polymerization-enhanced intersystem crossing: New strategy to achieve long-lived excitons. Macromol. Rapid Commun. 2015, 36, 298-303. [CrossRef]

38. Singh, N.; Singh, S.; Ashraf, S.M.; Riaz, U. Experimental and theoretical studies of benzoquinone modified poly(orthophenylenediamine): Singlet oxygen generating oligomers. Colloid Polym. Sci. 2020, 298, 1443-1453. [CrossRef]

39. Johnson, K.R.; Vittardi, S.B.; Gracia-Nava, M.A.; Rack, J.J.; de Bettencourt-Dias, A. Wavelength-Dependent Singlet Oxygen Generation in Luminescent Lanthanide Complexes with a Pyridine-Bis(Carboxamide)-Terthiophene Sensitizer. Chem. Eur. J. 2020, 26, 7274-7280. [CrossRef] [PubMed]

40. Li, J.; Pu, K. Semiconducting Polymer Nanomaterials as Near-Infrared Photoactivatable Protherapeutics for Cancer. Acc. Chem. Res. 2020, 53, 752-762. [CrossRef]

41. Wang, Y.; Feng, L.; Wang, S. Conjugated Polymer Nanoparticles for Imaging, Cell Activity Regulation, and Therapy. Adv. Funct. Mater. 2019, 29, 1-20. [CrossRef]

42. Liu, B.L. Conjugated Polymers for Biological and Biomedical Applications; Wiley-VCH Verlag GmbH \& Co. KGaA: Weinheim, Germany, 2018.

43. Nezakati, T.; Seifalian, A.; Tan, A.; Seifalian, A.M. Conductive Polymers: Opportunities and Challenges in Biomedical Applications. Chem. Rev. 2018, 118, 6766-6843. [CrossRef] [PubMed]

44. Fan, Z.; Xu, H. Recent Progress in the Biological Applications of Reactive Oxygen Species-Responsive Polymers. Polym. Rev. 2020, 60, 114-143. [CrossRef] 
45. Gesquiere, A. Photodynamic Therapy with Conjugated Polymer Nanoparticles: Recent Advances and Therapeutic Considerations. J. Cancer Treat. Diagn. 2018, 2, 1-6. [CrossRef]

46. Nguyen, V.N.; Yan, Y.; Zhao, J.; Yoon, J. Heavy-Atom-Free Photosensitizers: From Molecular Design to Applications in the Photodynamic Therapy of Cancer. Acc. Chem. Res. 2021, 54, 207-220. [CrossRef] [PubMed]

47. Maldonado-Carmona, N.; Ouk, T.S.; Calvete, M.J.F.; Pereira, M.M.; Villandier, N.; Leroy-Lhez, S. Conjugating biomaterials with photosensitizers: Advances and perspectives for photodynamic antimicrobial chemotherapy. Photochem. Photobiol. Sci. 2020, 19, 445-461. [CrossRef]

48. Qin, Y.; Chen, L.J.; Dong, F.; Jiang, S.T.; Yin, G.Q.; Li, X.; Tian, Y.; Yang, H.B. Light-Controlled Generation of Singlet Oxygen within a Discrete Dual-Stage Metallacycle for Cancer Therapy. J. Am. Chem. Soc. 2019, 141, 8943-8950. [CrossRef] [PubMed]

49. Jiang, J.; Qian, Y.; Xu, Z.; Lv, Z.; Tao, P.; Xie, M.; Liu, S.; Huang, W.; Zhao, Q. Enhancing singlet oxygen generation in semiconducting polymer nanoparticles through fluorescence resonance energy transfer for tumor treatment. Chem. Sci. 2019, 10, 5085-5094. [CrossRef]

50. Xiang, Z.; Zhu, L.; Qi, L.; Yan, L.; Xue, Y.; Wang, D.; Chen, J.F.; Dai, L. Two-Dimensional Fully Conjugated Polymeric Photosensitizers for Advanced Photodynamic Therapy. Chem. Mater. 2016, 28, 8651-8658. [CrossRef]

51. Chang, K.; Tang, Y.; Fang, X.; Yin, S.; Xu, H.; Wu, C. Incorporation of Porphyrin to $\pi$-Conjugated Backbone for Polymer-DotSensitized Photodynamic Therapy. Biomacromolecules 2016, 17, 2128-2136. [CrossRef] [PubMed]

52. Khatoon, S.S.; Chen, Y.; Zhao, H.; Lv, F.; Liu, L.; Wang, S. In situ self-assembly of conjugated polyelectrolytes for cancer targeted imaging and photodynamic therapy. Biomater. Sci. 2020, 8, 2156-2163. [CrossRef]

53. Li, S.; Chang, K.; Sun, K.; Tang, Y.; Cui, N.; Wang, Y.; Qin, W.; Xu, H.; Wu, C. Amplified Singlet Oxygen Generation in Semiconductor Polymer Dots for Photodynamic Cancer Therapy. ACS Appl. Mater. Interfaces 2016, 8, 3624-3634. [CrossRef] [PubMed]

54. Xing, C.; Liu, L.; Tang, H.; Feng, X.; Yang, Q.; Wang, S.; Bazan, G.C. Design guidelines for conjugated polymers with light-activated anticancer activity. Adv. Funct. Mater. 2011, 21, 4058-4067. [CrossRef]

55. $\mathrm{Wu}, \mathrm{C} . ; \mathrm{Xu}, \mathrm{Q} . \mathrm{H}$. Enhanced one- and two-photon excitation emission of a porphyrin photosensitizer by FRET from a conjugated polyelectrolyte. Macromol. Rapid Commun. 2009, 30, 504-508. [CrossRef]

56. Doshi, M.; Krienke, M.; Khederzadeh, S.; Sanchez, H.; Copik, A.; Oyer, J.; Gesquiere, A.J. Conducting polymer nanoparticles for targeted cancer therapy. RSC Adv. 2015, 5, 37943-37956. [CrossRef]

57. Wu, Y.; Zhen, Y.; Ma, Y.; Zheng, R.; Wang, Z.; Fu, H. Exceptional intersystem crossing in Di(perylene bisimide)s: A structural platform toward photosensitizers for singlet oxygen generation. J. Phys. Chem. Lett. 2010, 1, 2499-2502. [CrossRef]

58. Kuehne, A.J.C. Conjugated Polymer Nanoparticles toward in Vivo Theranostics-Focus on Targeting, Imaging, Therapy, and the Importance of Clearance. Adv. Biosyst. 2017, 1, 1700100. [CrossRef] [PubMed]

59. Wang, S.; Wu, W.; Manghnani, P.; Xu, S.; Wang, Y.; Goh, C.C.; Ng, L.G.; Liu, B. Polymerization-Enhanced Two-Photon Photosensitization for Precise Photodynamic Therapy. ACS Nano 2019, 13, 3095-3105. [CrossRef] [PubMed]

60. Shen, X.; Li, S.; Li, L.; Yao, S.Q.; Xu, Q.H. Highly efficient, conjugated-polymer-based nano-photosensitizers for selectively targeted two-photon photodynamic therapy and imaging of cancer cells. Chem. Eur. J. 2015, 21, 2214-2221. [CrossRef] [PubMed]

61. Yuan, H.; Wang, B.; Lv, F.; Liu, L.; Wang, S. Conjugated-polymer-based energy-transfer systems for antimicrobial and anticancer applications. Adv. Mater. 2014, 26, 6978-6982. [CrossRef]

62. Grimland, J.L.; Wu, C.; Ramoutar, R.R.; Brumaghim, J.L.; McNeill, J. Photosensitizer-doped conjugated polymer nanoparticles with high cross-sections for one- and two-photon excitation. Nanoscale 2011, 3, 1451-1455. [CrossRef] [PubMed]

63. Shen, X.; Li, L.; Wu, H.; Yao, S.Q.; Xu, Q.H. Photosensitizer-doped conjugated polymer nanoparticles for simultaneous two-photon imaging and two-photon photodynamic therapy in living cells. Nanoscale 2011, 3, 5140-5146. [CrossRef] [PubMed]

64. Shen, X.; He, F.; Wu, J.; Xu, G.Q.; Yao, S.Q.; Xu, Q.H. Enhanced two-photon singlet oxygen generation by photosensitizer-doped conjugated polymer nanoparticles. Langmuir 2011, 27, 1739-1744. [CrossRef] [PubMed]

65. Li, S.; Jiang, X.F.; Xu, Q.H. Polyfluorene based conjugated polymer nanoparticles for two-photon live cell imaging. Sci. China Chem. 2018, 61, 88-96. [CrossRef]

66. Shen, X.; Li, L.; Min Chan, A.C.; Gao, N.; Yao, S.Q.; Xu, Q.H. Water-Soluble Conjugated Polymers for Simultaneous Two-Photon Cell Imaging and Two-Photon Photodynamic Therapy. Adv. Opt. Mater. 2013, 1, 92-99. [CrossRef]

67. Feng, Z.; Tao, P.; Zou, L.; Gao, P.; Liu, Y.; Liu, X.; Wang, H.; Liu, S.; Dong, Q.; Li, J.; et al. Hyperbranched Phosphorescent Conjugated Polymer Dots with Iridium(III) Complex as the Core for Hypoxia Imaging and Photodynamic Therapy. ACS Appl. Mater. Interfaces 2017, 9, 28319-28330. [CrossRef]

68. Duan, X.; Jiang, X.F.; Hu, D.; Liu, P.; Li, S.; Huang, F.; Ma, Y.; Xu, Q.H.; Cao, Y. Red emitting conjugated polymer based nanophotosensitizers for selectively targeted two-photon excitation imaging guided photodynamic therapy. Nanoscale 2019, 11, 185-192. [CrossRef]

69. Zhao, H.; Hu, W.; Ma, H.; Jiang, R.; Tang, Y.; Ji, Y.; Lu, X.; Hou, B.; Deng, W.; Huang, W.; et al. Photo-Induced Charge-Variable Conjugated Polyelectrolyte Brushes Encapsulating Upconversion Nanoparticles for Promoted siRNA Release and Collaborative Photodynamic Therapy under NIR Light Irradiation. Adv. Funct. Mater. 2017, 27, 1-14. [CrossRef]

70. Feng, G.; Fang, Y.; Liu, J.; Geng, J.; Ding, D.; Liu, B. Multifunctional Conjugated Polymer Nanoparticles for Image-Guided Photodynamic and Photothermal Therapy. Small 2017, 13, 1-12. [CrossRef] [PubMed] 
71. Li, G.; Zhou, R.; Zhao, W.; Yu, B.; Zhou, J.; Liu, S.; Huang, W.; Zhao, Q. Photothermally Responsive Conjugated Polymeric Singlet Oxygen Carrier for Phase Change-Controlled and Sustainable Phototherapy for Hypoxic Tumor. Research 2020, $2020,1-14$. [CrossRef]

72. Wainwright, M.; Crossley, K.B. Photosensitising agents-Circumventing resistance and breaking down biofilms: A review. Int. Biodeterior. Biodegrad. 2004, 53, 119-126. [CrossRef]

73. Spagnul, C.; Turner, L.C.; Boyle, R.W. Immobilized photosensitizers for antimicrobial applications. J. Photochem. Photobiol. B Biol. 2015, 150, 11-30. [CrossRef]

74. Sautrot-Ba, P.; Jockusch, S.; Nguyen, T.T.T.; Grande, D.; Chiapionne, A.; Abbad-Andaloussi, S.; Pan, M.; Méallet-Renault, R.; Versace, D.L. Photoinduced synthesis of antibacterial hydrogel from aqueous photoinitiating system. Eur. Polym. J. 2020, 138, 109936. [CrossRef]

75. Ringot, C.; Sol, V.; Granet, R.; Krausz, P. Porphyrin-grafted cellulose fabric: New photobactericidal material obtained by "Click-Chemistry" reaction. Mater. Lett. 2009, 63, 1889-1891. [CrossRef]

76. Xing, C.; Xu, Q.; Tang, H.; Liu, L.; Wang, S. Conjugated polymer/porphyrin complexes for efficient energy transfer and improving light-activated antibacterial activity. J. Am. Chem. Soc. 2009, 131, 13117-13124. [CrossRef] [PubMed]

77. Parthasarathy, A.; Goswami, S.; Corbitt, T.S.; Ji, E.; Dascier, D.; Whitten, D.G.; Schanze, K.S. Photophysics and light-activated biocidal activity of visible-light- absorbing conjugated oligomers. ACS Appl. Mater. Interfaces 2013, 5, 4516-4520. [CrossRef] [PubMed]

78. Zhai, L.; Zhang, Z.; Zhao, Y.; Tang, Y. Efficient Antibacterial Performance and Effect of Structure on Property Based on Cationic Conjugated Polymers. Macromolecules 2018, 51, 7239-7247. [CrossRef]

79. Zhang, P.; Li, S.; Chen, H.; Wang, X.; Liu, L.; Lv, F.; Wang, S. Biofilm Inhibition and Elimination Regulated by Cationic Conjugated Polymers. ACS Appl. Mater. Interfaces 2017, 9, 16933-16938. [CrossRef]

80. Zehra, N.; Dutta, D.; Malik, A.H.; Ghosh, S.S.; Iyer, P.K. Fluorescence Resonance Energy Transfer-Based Wash-Free Bacterial Imaging and Antibacterial Application Using a Cationic Conjugated Polyelectrolyte. ACS Appl. Mater. Interfaces 2018, 10, 27603-27611. [CrossRef]

81. Xu, Q.; He, P.; Wang, J.; Chen, H.; Lv, F.; Liu, L.; Wang, S.; Yoon, J. Antimicrobial activity of a conjugated polymer with cationic backbone. Dye. Pigment. 2019, 160, 519-523. [CrossRef]

82. Bai, H.; Zhang, H.; Hu, R.; Chen, H.; Lv, F.; Liu, L.; Wang, S. Supramolecular conjugated polymer systems with controlled antibacterial activity. Langmuir 2017, 33, 1116-1120. [CrossRef] [PubMed]

83. Zhao, Q.; Li, J.; Zhang, X.; Li, Z.; Tang, Y. Cationic Oligo(thiophene ethynylene) with Broad-Spectrum and High Antibacterial Efficiency under White Light and Specific Biocidal Activity against S. aureus in Dark. ACS Appl. Mater. Interfaces 2016, 8 , 1019-1024. [CrossRef] [PubMed]

84. Wang, Y.; Jett, S.D.; Crum, J.; Schanze, K.S.; Chi, E.Y.; Whitten, D.G. Understanding the dark and light-enhanced bactericidal action of cationic conjugated polyelectrolytes and oligomers. Langmuir 2013, 29, 781-792. [CrossRef]

85. Wang, Y.; Corbitt, T.S.; Jett, S.D.; Tang, Y.; Schanze, K.S.; Chi, E.Y.; Whitten, D.G. Direct visualization of bactericidal action of cationic conjugated polyelectrolytes and oligomers. Langmuir 2012, 28, 65-70. [CrossRef] [PubMed]

86. Ma, B.C.; Ghasimi, S.; Landfester, K.; Zhang, K.A.I. Enhanced visible light promoted antibacterial efficiency of conjugated microporous polymer nanoparticles via molecular doping. J. Mater. Chem. B 2016, 4, 5112-5118. [CrossRef]

87. Zhou, T.; Hu, R.; Wang, L.; Qiu, Y.; Zhang, G.; Deng, Q.; Zhang, H.; Yin, P.; Situ, B.; Zhan, C.; et al. An AIE-Active Conjugated Polymer with High ROS-Generation Ability and Biocompatibility for Efficient Photodynamic Therapy of Bacterial Infections. Angew. Chem. Int. Ed. 2020, 59, 9952-9956. [CrossRef] [PubMed]

88. Wang, H.; Guo, L.; Wang, Y.; Feng, L. Bactericidal activity-tunable conjugated polymers as a human-friendly bactericide for the treatment of wound infections. Biomater. Sci. 2019, 7, 3788-3794. [CrossRef]

89. Xing, C.; Yang, G.; Liu, L.; Yang, Q.; Lv, F.; Wang, S. Conjugated polymers for light-activated antifungal activity. Small 2012, 8, 525-529. [CrossRef] [PubMed]

90. Jagadesan, P.; Yu, Z.; Barboza-Ramos, I.; Lara, H.H.; Vazquez-Munoz, R.; López-Ribot, J.L.; Schanze, K.S. Light-Activated Antifungal Properties of Imidazolium-Functionalized Cationic Conjugated Polymers. Chem. Mater. 2020, 32, 6186-6196. [CrossRef]

91. Schanze, K.S.; Whitten, D.G.; Kell, A.M.; Chi, E.Y.; Ista, L.K.; Monge, F.A.; Jagadesan, P.; Bondu, V.; Donabedian, P.L. Highly Effective Inactivation of SARS-CoV-2 by Conjugated Polymers and Oligomers. ACS Appl. Mater. Interfaces 2020, 12, 55688-55695. [CrossRef]

92. Montagnon, T.; Kalaitzakis, D.; Triantafyllakis, M.; Stratakis, M.; Vassilikogiannakis, G. Furans and singlet oxygen-Why there is more to come from this powerful partnership. Chem. Commun. 2014, 50, 15480-15498. [CrossRef] [PubMed]

93. Qu, Z. Reactivities of singlet oxygen: Open-shell or closed-shell? Phys. Chem. Chem. Phys. 2020, 22, 13373-13377. [CrossRef]

94. Chakraborty, J.; Nath, I.; Song, S.; Mohamed, S.; Khan, A.; Heynderickx, P.M.; Verpoort, F. Porous organic polymer composites as surging catalysts for visible-light-driven chemical transformations and pollutant degradation. J. Photochem. Photobiol. C Photochem. Rev. 2019, 41, 100319. [CrossRef]

95. Ren, W.; Cheng, J.; Ou, H.; Huang, C.; Anpo, M.; Wang, X. Optimizing the crystallization process of conjugated polymer photocatalysts to promote electron transfer and molecular oxygen activation. J. Catal. 2020, 389, 636-645. [CrossRef] 
96. Li, R.; Byun, J.; Huang, W.; Ayed, C.; Wang, L.; Zhang, K.A.I. Poly(benzothiadiazoles) and Their Derivatives as Heterogeneous Photocatalysts for Visible-Light-Driven Chemical Transformations. ACS Catal. 2018, 8, 4735-4750. [CrossRef]

97. Ronzani, F.; Costarramone, N.; Blanc, S.; Benabbou, A.K.; Le Bechec, M.; Pigot, T.; Oelgemöller, M.; Lacombe, S. Visible-light photosensitized oxidation of $\alpha$-terpinene using novel silica-supported sensitizers: Photooxygenation vs. photodehydrogenation. J. Catal. 2013, 303, 164-174. [CrossRef]

98. Tobin, J.M.; McCabe, T.J.D.; Prentice, A.W.; Holzer, S.; Lloyd, G.O.; Paterson, M.J.; Arrighi, V.; Cormack, P.A.G.; Vilela, F. Polymer-Supported Photosensitizers for Oxidative Organic Transformations in Flow and under Visible Light Irradiation. ACS Catal. 2017, 7, 4602-4612. [CrossRef]

99. Ma, B.C.; Ghasimi, S.; Landfester, K.; Vilela, F.; Zhang, K.A.I. Conjugated microporous polymer nanoparticles with enhanced dispersibility and water compatibility for photocatalytic applications. J. Mater. Chem. A 2015, 3, 16064-16071. [CrossRef]

100. Xiang, Y.; Wang, X.; Zhang, X.; Hou, H.; Dai, K.; Huang, Q.; Chen, H. Enhanced visible light photocatalytic activity of TiO2 assisted by organic semiconductors: A structure optimization strategy of conjugated polymers. J. Mater. Chem. A 2017, 6, 153-159. [CrossRef]

101. Zhi, Y.; Ma, S.; Xia, H.; Zhang, Y.; Shi, Z.; Mu, Y.; Liu, X. Construction of donor-acceptor type conjugated microporous polymers: A fascinating strategy for the development of efficient heterogeneous photocatalysts in organic synthesis. Appl. Catal. B Environ. 2019, 244, 36-44. [CrossRef]

102. Li, L.; Cai, Z. Structure control and photocatalytic performance of porous conjugated polymers based on perylene diimide. Polym. Chem. 2016, 7, 4937-4943. [CrossRef]

103. Zhang, X.; Sun, R.; Sun, S.; Ren, F.; Chen, X.; Wu, L.; Xing, R. Metal-Free Organic Optoelectronic Molecule as a Highly Efficient Photocatalyst for the Degradation of Organic Pollutants. ACS Omega 2019, 4, 6068-6076. [CrossRef]

104. Xu, Y.; Jin, S.; Xu, H.; Nagai, A.; Jiang, D. Conjugated microporous polymers: Design, synthesis and application. Chem. Soc. Rev. 2013, 42, 8012-8031. [CrossRef]

105. Rose, M. Nanoporous polymers: Bridging the gap between molecular and solid catalysts? ChemCatChem 2014, 6, 1166-1182. [CrossRef]

106. Liras, M.; Iglesias, M.; Sánchez, F. Conjugated Microporous Polymers Incorporating BODIPY Moieties as Light-Emitting Materials and Recyclable Visible-Light Photocatalysts. Macromolecules 2016, 49, 1666-1673. [CrossRef]

107. Zhi, Y.; Yao, Z.; Jiang, W.; Xia, H.; Shi, Z.; Mu, Y.; Liu, X. Conjugated Microporous Polymers as Heterogeneous Photocatalysts for Efficient Degradation of a Mustard-Gas Simulant. ACS Appl. Mater. Interfaces 2019, 11, 37578-37585. [CrossRef] [PubMed]

108. Wang, T.X.; Liang, H.P.; Anito, D.A.; Ding, X.; Han, B.H. Emerging applications of porous organic polymers in visible-light photocatalysis. J. Mater. Chem. A 2020, 8, 7003-7034. [CrossRef]

109. Li, A.; Tan, C.; Yuan, T.; Liang, J.; Gao, D.; Tan, Y.; Jiang, Y. Efficient photocatalytic oxidation sensitized by conjugated polymers in a batch reaction and microreactors under visible light. J. Mater. Chem. A 2018, 6, 15927-15932. [CrossRef]

110. Zhou, Y.B.; Zhan, Z.P. Conjugated Microporous Polymers for Heterogeneous Catalysis. Chem. Asian J. 2018, 13, 9-19. [CrossRef]

111. Luo, S.; Zeng, Z.; Zeng, G.; Liu, Z.; Xiao, R.; Xu, P.; Wang, H.; Huang, D.; Liu, Y.; Shao, B.; et al. Recent advances in conjugated microporous polymers for photocatalysis: Designs, applications, and prospects. J. Mater. Chem. A 2020, 8, 6434-6470. [CrossRef]

112. Xiao, J.; Liu, X.; Pan, L.; Shi, C.; Zhang, X.; Zou, J.J. Heterogeneous Photocatalytic Organic Transformation Reactions Using Conjugated Polymers-Based Materials. ACS Catal. 2020, 10, 12256-12283. [CrossRef]

113. Wang, Z.J.; Ghasimi, S.; Landfester, K.; Zhang, K.A.I. Highly porous conjugated polymers for selective oxidation of organic sulfides under visible light. Chem. Commun. 2014, 50, 8177-8180. [CrossRef] [PubMed]

114. Ding, X.; Han, B.H. Metallophthalocyanine-based conjugated microporous polymers as highly efficient photosensitizers for singlet oxygen generation. Angew. Chem. Int. Ed. 2015, 54, 6536-6539. [CrossRef] [PubMed]

115. Ding, X.; Han, B.H. Copper phthalocyanine-based CMPs with various internal structures and functionalities. Chem. Commun. 2015, 51, 12783-12786. [CrossRef] [PubMed]

116. Hynek, J.; Rathouský, J.; Demel, J.; Lang, K. Design of porphyrin-based conjugated microporous polymers with enhanced singlet oxygen productivity. RSC Adv. 2016, 6, 44279-44287. [CrossRef]

117. Park, K.C.; Cho, J.; Lee, C.Y. Porphyrin and pyrene-based conjugated microporous polymer for efficient sequestration of $\mathrm{CO}_{2}$ and iodine and photosensitization for singlet oxygen generation. RSC Adv. 2016, 6, 75478-75481. [CrossRef]

118. Feng, X.; Ding, X.; Chen, L.; Wu, Y.; Liu, L.; Addicoat, M.; Irle, S.; Dong, Y.; Jiang, D. Two-dimensional artificial light-harvesting antennae with predesigned high-order structure and robust photosensitising activity. Sci. Rep. 2016, 6, 32944. [CrossRef]

119. Xu, Q.; Gao, Y.; Wu, X.; Hang, H.; Li, H.; Chen, Y.; Wang, W.; Tong, H. Subphthalocyanine-based conjugated porous polymers for efficient singlet oxygen generation. New J. Chem. 2019, 43, 16385-16390. [CrossRef]

120. Wu, W.; Xu, S.; Qi, G.; Zhu, H.; Hu, F.; Liu, Z.; Zhang, D.; Liu, B. A Cross-linked Conjugated Polymer Photosensitizer Enables Efficient Sunlight-Induced Photooxidation. Angew. Chem. Int. Ed. 2019, 58, 3062-3066. [CrossRef] [PubMed]

121. Luo, J.; Lu, J.; Zhang, J. Carbazole-triazine based donor-acceptor porous organic frameworks for efficient visible-light photocatalytic aerobic oxidation reactions. J. Mater. Chem. A 2018, 6, 15154-15161. [CrossRef]

122. Wang, Z.J.; Ghasimi, S.; Landfester, K.; Zhang, K.A.I. Molecular Structural Design of Conjugated Microporous Poly(Benzooxadiazole) Networks for Enhanced Photocatalytic Activity with Visible Light. Adv. Mater. 2015, 27, 6265-6270. [CrossRef] [PubMed] 
123. Wang, L.; Huang, W.; Li, R.; Gehrig, D.; Blom, P.W.M.; Landfester, K.; Zhang, K.A.I. Structural Design Principle of Small-Molecule Organic Semiconductors for Metal-Free, Visible-Light-Promoted Photocatalysis. Angew. Chem. Int. Ed. 2016, 55, $9783-9787$. [CrossRef]

124. Zhang, K.; Vobecka, Z.; Tauer, K.; Antonietti, M.; Vilela, F. $\pi$-Conjugated polyHIPEs as highly efficient and reusable heterogeneous photosensitizers. Chem. Commun. 2013, 49, 11158-11160. [CrossRef]

125. Wang, Z.J.; Ghasimi, S.; Landfester, K.; Zhang, K.A.I. A conjugated porous poly-benzobisthiadiazole network for a visible light-driven photoredox reaction. J. Mater. Chem. A 2014, 2, 18720-18724. [CrossRef]

126. Dai, C.; Liu, B. Conjugated polymers for visible-light-driven photocatalysis. Energy Environ. Sci. 2020, 13, 24-52. [CrossRef]

127. Ren, S.; Dawson, R.; Adams, D.J.; Cooper, A.I. Low band-gap benzothiadiazole conjugated microporous polymers. Polym. Chem. 2013, 4, 5585-5590. [CrossRef]

128. Zhang, K.; Kopetzki, D.; Seeberger, P.H.; Antonietti, M.; Vilela, F. Surface area control and photocatalytic activity of conjugated microporous poly(benzothiadiazole) networks. Angew. Chem. Int. Ed. 2013, 52, 1432-1436. [CrossRef] [PubMed]

129. Urakami, H.; Zhang, K.; Vilela, F. Modification of conjugated microporous poly-benzothiadiazole for photosensitized singlet oxygen generation in water. Chem. Commun. 2013, 49, 2353-2355. [CrossRef] [PubMed]

130. Banfi, S.; Nasini, G.; Zaza, S.; Caruso, E. Synthesis and photo-physical properties of a series of BODIPY dyes. Tetrahedron 2013, 69, 4845-4856. [CrossRef]

131. Wang, Z.; Hong, X.; Zong, S.; Tang, C.; Cui, Y.; Zheng, Q. BODIPY-doped silica nanoparticles with reduced dye leakage and enhanced singlet oxygen generation. Sci. Rep. 2015, 5, 12602. [CrossRef] [PubMed]

132. Wu, W.; Geng, Y.; Fan, W.; Li, Z.; Zhan, L.; Wu, X.; Zheng, J.; Zhao, J.; Wu, M. BODIPY-based photosensitizers with intense visible light harvesting ability and high $1 \mathrm{O} 2$ quantum yield in aqueous solution. RSC Adv. 2014, 4, 51349-51352. [CrossRef]

133. Jiang, X.D.; Xi, D.; Le Guennic, B.; Guan, J.; Jacquemin, D.; Guan, J.; Xiao, L.J. Synthesis of NIR naphthyl-containing aza-BODIPYs and measure of the singlet oxygen generation. Tetrahedron 2015, 71, 7676-7680. [CrossRef]

134. Zhang, X.F.; Yang, X. Photosensitizer that selectively generates singlet oxygen in nonpolar environments: Photophysical mechanism and efficiency for a covalent BODIPY dimer. J. Phys. Chem. B 2013, 117, 9050-9055. [CrossRef] [PubMed]

135. Bandyopadhyay, S.; Kundu, S.; Giri, A.; Patra, A. A smart photosensitizer based on a red emitting solution processable porous polymer: Generation of reactive oxygen species. Chem. Commun. 2018, 54, 9123-9126. [CrossRef] [PubMed]

136. Tobin, J.M.; Liu, J.; Hayes, H.; Demleitner, M.; Ellis, D.; Arrighi, V.; Xu, Z.; Vilela, F. BODIPY-based conjugated microporous polymers as reusable heterogeneous photosensitisers in a photochemical flow reactor. Polym. Chem. 2016, 7, 6662-6670. [CrossRef]

137. Blacha-Grzechnik, A.; Drewniak, A.; Walczak, K.Z.; Szindler, M.; Ledwon, P. Efficient generation of singlet oxygen by perylene diimide photosensitizers covalently bound to conjugate polymers. J. Photochem. Photobiol. A Chem. 2020, 388, 112161. [CrossRef]

138. Piwowar, K.; Blacha-Grzechnik, A.; Turczyn, R.; Zak, J. Electropolymerized phenothiazines for the photochemical generation of singlet oxygen. Electrochim. Acta 2014, 141, 182-188. [CrossRef]

139. Blacha-Grzechnik, A.; Piwowar, K.; Zdyb, T.; Krzywiecki, M. Formation of poly(Azure A)-C60 photoactive layer as a novel approach in the heterogeneous photogeneration of singlet oxygen. Appl. Surf. Sci. 2018, 457, 221-228. [CrossRef]

140. Blacha-Grzechnik, A.; Krzywiecki, M.; Motyka, R.; Czichy, M. Electrochemically Polymerized Terthiopehene-C60 Dyads for the Photochemical Generation of Singlet Oxygen. J. Phys. Chem. C 2019, 123, 25915-25924. [CrossRef]

141. Nyga, A.; Motyka, R.; Bussetti, G.; Calloni, A.; Sangarashettyhalli, M.; Fijak, S.; Pluczyk-Malek, S.; Data, P.; Blacha-Grzechnik, A Electrochemically deposited poly(selenophene)-fullerene photoactive layer: Tuning of the spectroscopic properties towards visible light-driven generation of singlet oxygen. Appl. Surf. Sci. 2020, 525, 146594. [CrossRef]

142. Zhou, J.; Wang, Y.; Cui, Z.; Hu, Y.; Hao, X.; Wang, Y.; Zou, Z. Ultrathin conjugated polymer nanosheets as highly efficient photocatalyst for visible light driven oxygen activation. Appl. Catal. B Environ. 2020, 277, 119228. [CrossRef]

143. Cui, X.; Li, Y.; Dong, W.; Liu, D.; Duan, Q. Microwave-assisted synthesis of novel imine-linked copper porphyrin conjugated microporous polymers as heterogeneous photocatalysts. React. Funct. Polym. 2020, 154, 104633. [CrossRef]

144. Chakraborty, J.; Nath, I.; Jabbour, C.; Aljammal, N.; Song, S.; Kao, C.M.; Heynderickx, P.M.; Verpoort, F. Novel rapid room temperature synthesis of conjugated microporous polymer for metal-free photocatalytic degradation of fluoroquinolones. $J$. Hazard. Mater. 2020, 398, 122928. [CrossRef] [PubMed]

145. Piwowar, K.; Blacha-Grzechnik, A.; Bernas, P.; Zak, J. Phenol degradation in heterogeneous system generating singlet oxygen employing light activated electropolymerized phenothiazines. Appl. Surf. Sci. 2015, 359, 426-431. [CrossRef]

146. Tanaka, S.; Enoki, T.; Imoto, H.; Ooyama, Y.; Ohshita, J.; Kato, T.; Naka, K. Highly Efficient Singlet Oxygen Generation and High Oxidation Resistance Enhanced by Arsole-Polymer-Based Photosensitizer: Application as a Recyclable Photooxidation Catalyst. Macromolecules 2020, 53, 2006-2013. [CrossRef]

147. Yu, Y.; Li, Y.; Li, Y.; Wang, H.; Zuo, Q.; Duan, Q. A 1D porphyrin-based rigid conjugated polymer as efficient and recyclable visible-light driven photocatalyst. React. Funct. Polym. 2019, 143, 104340. [CrossRef]

148. Shen, J.; Steinbach, R.; Tobin, J.M.; Mouro Nakata, M.; Bower, M.; McCoustra, M.R.S.; Bridle, H.; Arrighi, V.; Vilela, F. Photoactive and metal-free polyamide-based polymers for water and wastewater treatment under visible light irradiation. Appl. Catal. B Environ. 2016, 193, 226-233. [CrossRef] 